Gas Desorption and Adsorption Isotherm Studies of Coals in the Powder River Basin, Wyoming and Adjacent Basins in Wyoming and North Dakota
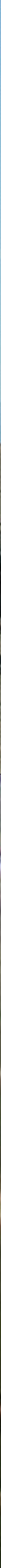


\section{Gas Desorption and Adsorption Isotherm Studies of Coals in the Powder River Basin, Wyoming and Adjacent Basins in Wyoming and North Dakota}

By Gary D. Stricker ${ }^{1}$, Romeo M. Flores ${ }^{1}$, Dwain E. McGarry², Dean P. Stillwell², Daniel J. Hoppe ${ }^{2}$, Cathy R. Stillwell2, Alan M. Ochs ${ }^{3}$, Margaret S. Ellis', Karl S. Osvald², Sharon L. Taylor ${ }^{2}$, Marjorie C. Thorvaldson², Michael H. Trippi ${ }^{4}$, Sherry D. Grose ${ }^{5}$, Fred J. Crockett ${ }^{2}$, and Asghar J. Shariff ${ }^{2}$

Prepared in cooperation with the Wyoming State Office Reservoir Management Group, Bureau of Land Management Casper, Wyoming

Open-File Report 2006-1174 


\section{U.S. Department of the Interior \\ Dirk Kempthorne, Secretary \\ U.S. Geological Survey \\ P. Patrick Leahy, Acting Director}

\section{U.S. Geological Survey, Reston, Virginia: 2006}

For product and ordering information:

World Wide Web: http://www.usgs.gov/pubprod

Telephone: 1-888-ASK-USGS

For more information on the USGS - the Federal source for science about the Earth, its natural and living resources, natural hazards, and the environment:

World Wide Web: http://www.usgs.gov

Telephone: 1-888-ASK-USGS

Any use of trade, product, or firm names is for descriptive purposes only and does not imply endorsement by the U.S. Government.

Although this report is in the public domain, permission must be secured from the individual copyright owners to reproduce any copyrighted materials contained within this report. 


\section{Contents}

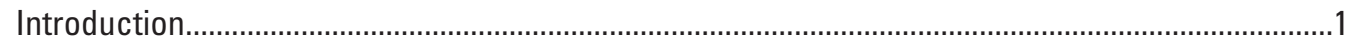

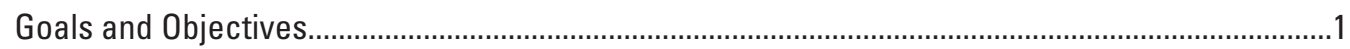

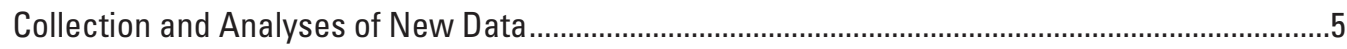

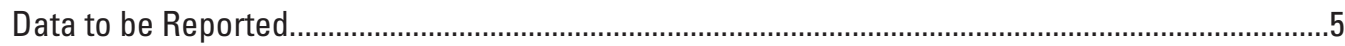

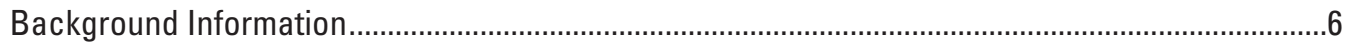

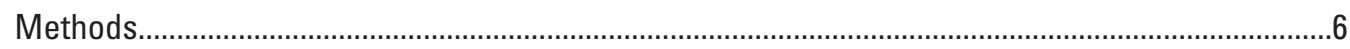

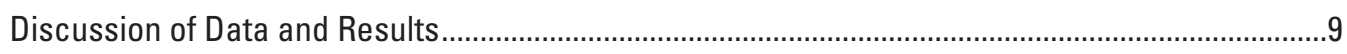

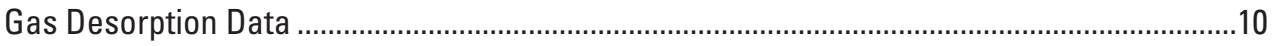

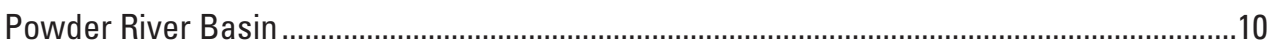

Gas Variations Within and Between the Same Coal Bed ................................................10

Gas Variations Between Stratigraphically Different Coal Beds .....................................10

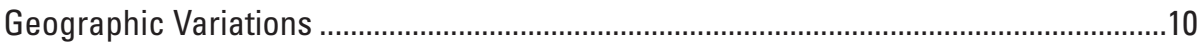

Depths of Coal Beds .................................................................................................

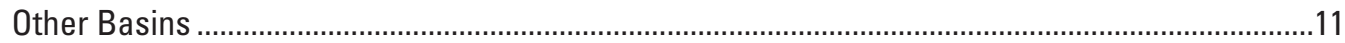

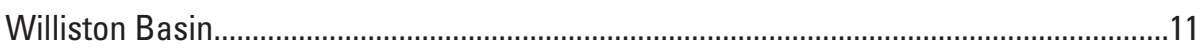

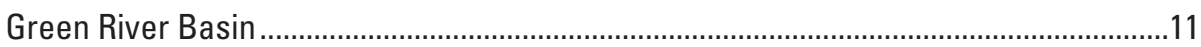

Interpretations of Gas Desorption Results …….....................................................................

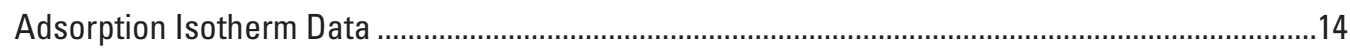

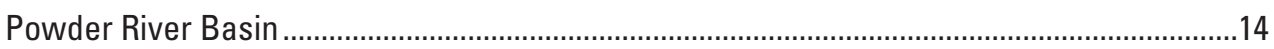

Langmuir Isotherms Within and Between the Same Coal Bed.....................................14

Langmuir Isotherms Between Stratigraphically Different Coal Beds.............................14

Langmuir Isotherms of Coal Beds at Various Depths ..................................................16

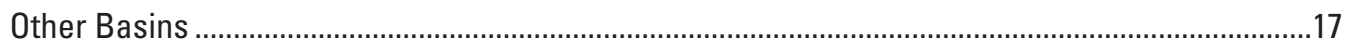

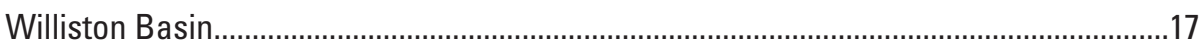

Green River Basin .....................................................................................................

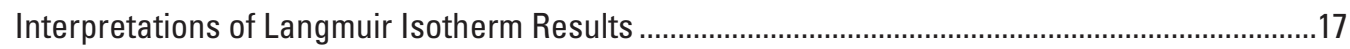

Apparent Rank Difference of Coal Beds .........................................................................17

Summary

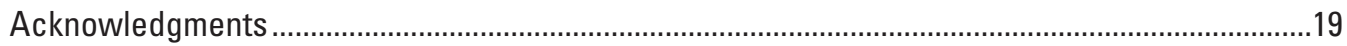

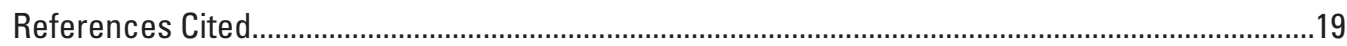

\section{Figures}

1. Location of core holes in the Powder River, Bighorn, Green River, and Williston Basins, Wyoming, Montana, and North and South Dakota ..

2. Drill site showing drilling rig and $30-\mathrm{ft}$ core barrel for collecting coal cores from a Peabody Natural Gas CBM well in the Powder River Basin, Wyoming ..............................5

3. Stratigraphic column of the Fort Union Formation in the Powder River Basin,

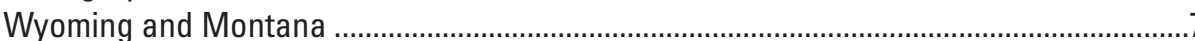

4. Measurement of a continuous core $(A)$ and cutting the core $(B)$ of a Fort Union coal bed in the Powder River Basin, Wyoming 
5. Airtight canisters $(A)$ used to collect coal cores $(B)$ for gas desorption

6. Desorption of gas using a graduated cylinder $(A)$ and heated water baths used to maintain reservoir temperature $(B)$

7. Trailer $(A)$ converted into a mobile field office $(B)$ and wet laboratory $(C)$ with water baths and gas desorption apparatus

8. Position of the Beulah coal bed in the Fort Union Formation, Williston Basin, Montana and North and South Dakota.

9. Position of the Deadman coal bed in the Fort Union Formation, Green River Basin, Wyoming.

10. Relations of total gas content with percent vitrain banding in the Peabody Natural Gas 31-1 well

11. Relations of total gas content with percent vitrain banding in the Peabody Natural Gas 35-1 well

12. Relations of total gas content with percent maceral types or lithotypes, density, and Gamma Ray logs in the MichiWest Energy 16-32 well.

13. General relations of total gas content and lithotypes in the MichiWest Energy 16-32 well

14. Average methane adsorption isotherm curve of subbituminous coals in the Powder River Basin, Wyoming and Montana.

15. Average methane adsorption isotherm curve of lignite coals in the Williston Basin, Montana and North and South Dakota

\section{Tables}

1a. Gas operators, well name, API number, state and basin name for core holes in this study

1b. Well name, core hole location, date cored, and date report sent to operator. 


\title{
Gas Desorption and Adsorption Isotherm Studies of Coals in the Powder River Basin, Wyoming and Adjacent Basins in Wyoming and North Dakota
}

\author{
By Gary D. Stricker ${ }^{1}$, Romeo M. Flores ${ }^{1}$, Dwain E. McGarry², Dean P. Stillwell2, Daniel J. Hoppe ${ }^{2}$, Cathy R. \\ Stillwell ${ }^{2}$, Alan M. Ochs ${ }^{3}$, Margaret S. Ellis' ${ }^{1}$, Karl S. Osvald², Sharon L. Taylor ${ }^{2}$, Marjorie C. Thorvaldson², \\ Michael H. Trippi ${ }^{4}$, Sherry D. Grose ${ }^{5}$, Fred J. Crockett ${ }^{2}$, and Asghar J. Shariff ${ }^{2}$
}

\section{Introduction}

The U.S. Geological Survey (USGS), in cooperation with the State Office, Reservoir Management Group (RMG), of the Bureau of Land Management (BLM) in Casper (Wyoming), investigated the coalbed methane (CBM) resources in the Powder River Basin (PRB), Wyoming and Montana (fig. 1), from 1999 to the present. Beginning in late 1999, the study also included the Williston Basin (WB) in Montana and North and South Dakota and Green River Basin (GRB) and Big Horn (BHB) Basin in Wyoming (fig. 1). The rapid development of CBM (referred to as coalbed natural gas by the BLM) during the early 1990s, and the lack of sufficient data for the BLM to fully assess and manage the resource in the PRB, in particular, gave impetus to the cooperative program.

An integral part of the joint USGS-BLM project was the participation of 25 gas operators (table 1a, see listing below) that entered individually into confidential agreements with the USGS (specifically, the central Energy Resources Team (CERT), Denver, Colorado), and whose cooperation was essential to the study. The arrangements were for the gas operators to drill and core coal-bed reservoirs at their cost, and for the USGS and BLM personnel to then desorb, analyze, and interpret the coal data with joint funding by the two agencies. Upon completion of analyses by the USGS, the data were to be shared with both the BLM and the gas operator that supplied the core, and then to be released or published $1 \mathrm{yr}$ after the report was submitted to the operator (submission dates for data reports to gas operators are given in table 1b).

The cooperating gas operators are: Ammonite Energy Texas Incorporated, Anadarko Petroleum, Barrett Resources
Corporation, Bill Barrett Corporation, Bridger Coal Company, The Coteau Properties Company, CMS Oil and Gas Company, Gregory Water and Energy Incorporated, Hudson Group LLC., J.M. Huber Corporation, Kennecott Energy (Jacobs Ranch Coal Company), Lance Oil and Gas, MichiWest Energy, Nance Petroleum Corporation, North Dakota Coal Company, Ocean Energy Inc., Pacific Incorporated, Peabody Natural Gas LLC, Pennaco Energy Inc., Pinnacle Gas Resources Inc., Quantum Energy LLC., Rim Operating Company, Southwestern Energy Production Company, Western Gas Resources, Williams Production RMT Company, and Yates Production Corp.

\section{Goals and Objectives}

BLM's main goal for this cooperative project, because of its responsibility to manage Federal CBM resources, is to obtain additional and improved gas-content values for gasin-place resource estimates, as well as better reservoir characterization, that will lead to a more reliable resource/reserve assessment in the PRB by its RMG. The objectives of the USGS are: (1) to collect new and more accurate data on the Fort Union coal-bed reservoirs in the PRB and other basins in Wyoming; (2) to enter into cooperative and confidential agreements with gas operators to core coal-bed reservoirs in order to maximize knowledge of resources of both agencies; (3) to provide BLM the results of analyses as soon as they become available, in order for the agency to make timely policy decisions on resource management; and (4) to assist BLM in efforts to better define coal bed reservoir properties in the PRB.

${ }^{1}$ U.S. Geological Survey, Denver, Colorado 80225

${ }^{2}$ Wyoming State Office Reservoir Management Group, Bureau of Land Management, Casper, Wyoming 82604

${ }^{3} 48401 \frac{1}{2}$. West $30^{\text {th }}$ Ave., Denver, Colorado 80212

${ }^{4}$ U.S. Geological Survey, Reston, Virginia 20192

${ }^{5}$ Casper Field Office, Bureau of Land Management, Casper, Wyoming 82604 


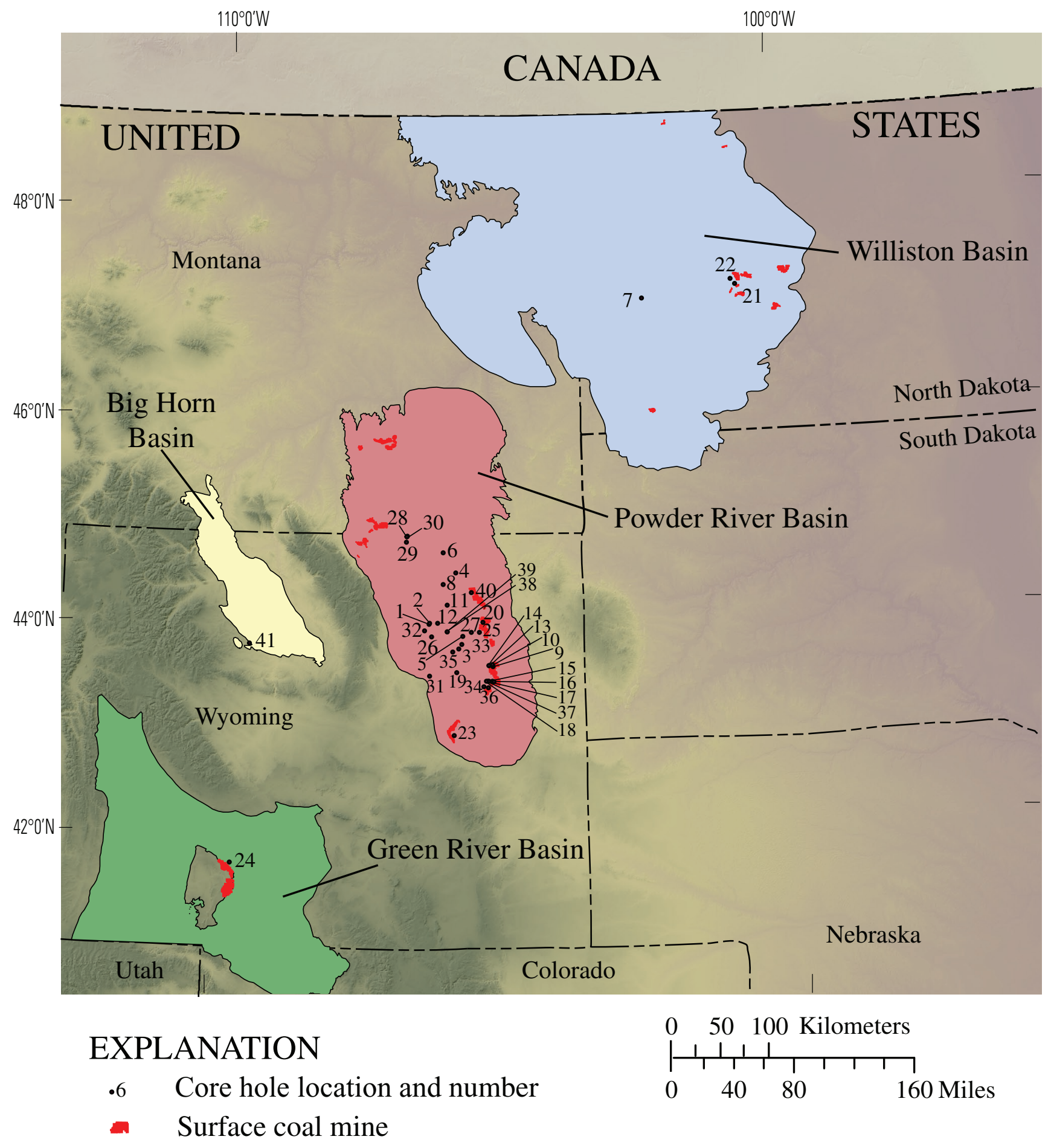

Figure 1. Map showing location of core holes in the Powder River, Bighorn, Green River, and Williston Basins, Wyoming, Montana, and North and South Dakota. Core hole numbers are keyed to table 1a. 
Table 1a. Gas operators, well name, API number, state and basin name for core holes in this study.

\begin{tabular}{|c|c|c|c|c|c|}
\hline $\begin{array}{l}\text { Core } \\
\text { hole } \\
\text { number }\end{array}$ & Core hole operator & Core hole name & $\begin{array}{c}\text { Amican } \\
\text { Petroleum } \\
\text { Institute (API) } \\
\text { number }^{1}\end{array}$ & State & Basin $^{2}$ \\
\hline 1 & MichiWest Energy Inc. & Pilot State16-14 & $049-019-21068$ & WY & PRB \\
\hline 2 & MichiWest Energy Inc. & Pilot State 16-32 & 049-019-21071 & WY & PRB \\
\hline 3 & Ocean Energy Inc. & Schlautmann 9-10-45-74WY (Ocean 43-10C) & 049-005-34173 & WY & PRB \\
\hline 4 & Pennaco Energy Inc. & Sorenson $2-33-54-74 \mathrm{~W}$ & 049-005-35137 & WY & PRB \\
\hline 5 & Barrett Resources Corporation & Haas 32-31 & 049-005-35287 & WY & PRB \\
\hline 6 & CMS Oil and Gas Company & West 6-19W & 049-005-35339 & WY & PRB \\
\hline 7 & Gregory Water and Energy Inc. & Leroy Gregory 1 & N.A. & ND & WB \\
\hline 8 & CMS Oil and Gas Company & Laramore 11-6C & 049-005-37516 & WY & PRB \\
\hline 9 & Kennecott Energy & Kennecott CBM-1 & N.A. & WY & PRB \\
\hline 10 & Kennecott Energy & Kennecott CBM-2 & N.A. & WY & PRB \\
\hline 11 & Barrett Resources Corporation & CARU State $22-16-5075 \mathrm{~W}$ & 049-005-38103 & WY & PRB \\
\hline 12 & Barrett Resources Corporation & Schoonover Road Unit (SRU) State 12-16-4876 & 049-005-36110 & WY & PRB \\
\hline 13 & Rim Operating Inc. & CBM H 11-04 & 049-005-37359 & WY & PRB \\
\hline 14 & Rim Operating Inc. & CBM C 33-1R & 049-005-37386 & WY & PRB \\
\hline 15 & Peabody Natural Gas, LLC. & PNG 34-1 & N.A. & WY & PRB \\
\hline 16 & Peabody Natural Gas, LLC. & PNG 33-1 & N.A. & WY & PRB \\
\hline 17 & Peabody Natural Gas, LLC. & PNG 31-1 & N.A. & WY & PRB \\
\hline 18 & Peabody Natural Gas, LLC. & PNG 35-1 & N.A. & WY & PRB \\
\hline 19 & Barrett Resources Corporation & All Night Creek (ANCU) Iberlin 21-33-4374 & 049-005-37965 & WY & PRB \\
\hline 20 & Peabody Natural Gas, LLC. & PNG 16-2 & N.A. & WY & PRB \\
\hline 21 & The Coteau Properties Co. & Coteau MC00250C & N.A. & ND & WB \\
\hline 22 & The Coteau Properties Co. & Coteau MC00251 & N.A. & ND & WB \\
\hline 23 & Ammonite Energy Texas, Inc. & Thomas Jefferson State 36-3 & 049-009-22996 & WY & PRB \\
\hline 24 & Bridger Coal Co. & BCX-9 & N.A. & WY & GRB \\
\hline 25 & Peabody Natural Gas, LLC. & PNG Duvall 13J-D & 049-005-44594 & WY & PRB \\
\hline 26 & Barrett Resources Corporation & KU Harriett 41-34-4777 & 049-019-21774 & WY & PRB \\
\hline 27 & Peabody Natural Gas, LLC. & PNG Carter-Federal 18F-D & 049-005-37063 & WY & PRB \\
\hline 28 & Nance Petroleum Corporation & Remington $58793007 \mathrm{~A}$ & 049-033-23127 & WY & PRB \\
\hline 29 & Nance Petroleum Corporation & Remington $57-79-18-03 \mathrm{R}$ & 049-033-23136 & WY & PRB \\
\hline 30 & Nance Petroleum Corporation & Remington $58793001 \mathrm{C}$ & 049-033-23131 & WY & PRB \\
\hline 31 & Williams Production RMT Company & Bullwacker Creek Unit (BCU) 32-9-4277 & 049-019-21969 & WY & PRB \\
\hline 32 & Lance Oil and Gas Company Inc. & Whiskey Draw Unit 12-12-4778 & $049-019-22873$ & WY & PRB \\
\hline 33 & Lance Oil and Gas Company Inc. & McBeth 12-30-4673-BG & 049-005-50378 & WY & PRB \\
\hline 34 & Williams Production RMT Company & State $23-16-4171$ & 049-005-50711 & WY & PRB \\
\hline 35 & Williams Production RMT Company & Groves $12-19-4574$ & 049-005-51276 & WY & PRB \\
\hline 36 & Peabody Natural Gas, LLC. & PNG 24-1 & N.A. & WY & PRB \\
\hline 37 & Peabody Natural Gas, LLC. & PNG 26-1 & N.A. & WY & PRB \\
\hline 38 & Bill Barrett Corporation $^{3}$ & State $21-16-4775 \mathrm{~W}$ & 049-005-52882 & WY & PRB \\
\hline 39 & Bill Barrett Corporation ${ }^{3}$ & State 21-16-4775BG & $049-005-52883$ & WY & PRB \\
\hline 40 & Peabody Natural Gas, LLC. ${ }^{3}$ & PNG Rawhide CBM 1 & N.A. & WY & PRB \\
\hline 41 & Pinnacle Gas Resources Inc. ${ }^{3}$ & Ilo Ridge 1 & $049-017-21286$ & WY & BHB \\
\hline
\end{tabular}

${ }^{1}$ N.A., no API number available.

${ }^{2}$ PRB, Powder River Basin; WB, Williston Basin; GRB, Green River Basin; BHB, Big Horn Basin.

${ }^{3}$ Data for this core hole not included in this report because of confidentiality agreement. 
Table 1b. Well name, core hole location, date cored, and date report sent to operator.

\begin{tabular}{|c|c|c|c|c|c|}
\hline Core hole name & $\begin{array}{l}\text { Decimal } \\
\text { latitude }\end{array}$ & $\begin{array}{l}\text { Decimal } \\
\text { longitude }\end{array}$ & Township and Range & $\begin{array}{l}\text { Date } \\
\text { cored }\end{array}$ & $\begin{array}{c}\text { Date } \\
\text { report } \\
\text { sent to } \\
\text { operator }\end{array}$ \\
\hline Pilot State16-14 & $44.12838 \mathrm{~N}$ & $106.12824 \mathrm{~W}$ & SW/4 SW/4 Sec 16 T48N R77W & 27-Jan-99 & Mar-00 \\
\hline Pilot State $16-32$ & $44.13568 \mathrm{~N}$ & $106.11822 \mathrm{~W}$ & SW/4 NE/4 Sec 16 T48N R77W & 7-Apr-99 & May-00 \\
\hline Schlautmann 9-10-45-74WY (Ocean 43-10C) & $43.88730 \mathrm{~N}$ & $105.73104 \mathrm{~W}$ & NE/4 SE/4 Sec 10 T45N R74W & 25-Jun-99 & Jun- 00 \\
\hline Sorenson $2-33-54-74 \mathrm{~W}$ & $44.62333 \mathrm{~N}$ & $105.76500 \mathrm{~W}$ & NW/4 NE/4 Sec 33 T54N R74W & 13-Aug-99 & Sep-00 \\
\hline Haas 32-31 & $44.00851 \mathrm{~N}$ & $105.67651 \mathrm{~W}$ & SW/4 NE/4 Sec 31 T47N R73W & 24-Sep-99 & Nov- 00 \\
\hline West 6-19W & $44.81796 \mathrm{~N}$ & $105.93621 \mathrm{~W}$ & SE/4 NW/4 Sec 19 T56N R75W & 27-Sep-99 & Dec-00 \\
\hline Leroy Gregory 1 & $47.23228 \mathrm{~N}$ & $103.14541 \mathrm{~W}$ & SE/4 SE/4 Sec 6 T143N R98W & 13-Oct-99 & Nov- 00 \\
\hline Laramore $11-6 \mathrm{C}$ & $44.51333 \mathrm{~N}$ & $105.93560 \mathrm{~W}$ & NE/4 SW/4 Sec 6 T52N R75W & 10-Dec-99 & Jan-01 \\
\hline Kennecott CBM-1 & $43.71728 \mathrm{~N}$ & $105.27447 \mathrm{~W}$ & SW/4 NW/4 Sec 9 T43N R70W & $5-J a n-00$ & Feb-01 \\
\hline Kennecott CBM-2 & $43.72136 \mathrm{~N}$ & $105.27680 \mathrm{~W}$ & SW/4 NW/4 Sec 9 T43N R70W & 6-Jan-00 & Mar-01 \\
\hline CARU State 22-16-5075W & $44.31003 \mathrm{~N}$ & $105.88602 \mathrm{~W}$ & SE/4 NW/4 Sec 16 T50N 75W & $20-$ Feb-00 & May-01 \\
\hline Schoonover Road Unit (SRU) State 12-16-4876 & $44.13523 \mathrm{~N}$ & $106.00883 \mathrm{~W}$ & $\mathrm{SW} / 4 \mathrm{NW} / 4 \mathrm{Sec} 16 \mathrm{~T} 48 \mathrm{~N}$ R76W & 29-Feb-00 & Jul-01 \\
\hline CBM H 11-04 & $43.73564 \mathrm{~N}$ & $105.27828 \mathrm{~W}$ & NW/4 NW4 Sec 4 T43N R70W & 22-Mar-00 & Sep-01 \\
\hline CBM C 33-1R & $43.72872 \mathrm{~N}$ & $105.32945 \mathrm{~W}$ & NW/4 SE/4 Sec 1 T43N R71W & 27-Apr-00 & Jan-02 \\
\hline PNG 34-1 & $43.57330 \mathrm{~N}$ & $105.26031 \mathrm{~W}$ & NE/4 NW/4 Sec 34 T42N R70W & 2-Jun-00 & Mar-02 \\
\hline PNG 33-1 & $43.57583 \mathrm{~N}$ & $105.28145 \mathrm{~W}$ & NE/4 NW/4 Sec 33 T42N R70W & 2-Jun-00 & Mar-02 \\
\hline PNG 31-1 & $43.57895 \mathrm{~N}$ & $105.32843 \mathrm{~W}$ & NE/4 NW/4 Sec 31 T42N R70W & 3-Jun-00 & Mar-02 \\
\hline PNG 35-1 & $43.57624 \mathrm{~N}$ & $105.35947 \mathrm{~W}$ & $\mathrm{SW} / 4 \mathrm{NE} / 4 \mathrm{Sec} 35 \mathrm{~T} 42 \mathrm{~N}$ R71W & 12-Jul-00 & Mar-02 \\
\hline All Night Creek (ANCU) Iberlin 21-33-4374 & $43.66122 \mathrm{~N}$ & $105.75760 \mathrm{~W}$ & NE/4 NW/4 Sec 33 T43N R74W & 14-Jul-00 & Mar-02 \\
\hline PNG 16-2 & $44.14510 \mathrm{~N}$ & $105.40291 \mathrm{~W}$ & NW/4 NW/4 Sec 9 T48N R71W & 31-Jul-00 & Mar-02 \\
\hline Coteau MC00250C & $47.33781 \mathrm{~N}$ & $101.82531 \mathrm{~W}$ & C SE/4 NE/4 36 T145N R88W & 22-Aug-00 & Apr-02 \\
\hline Coteau MC00251 & $47.38478 \mathrm{~N}$ & $101.88874 \mathrm{~W}$ & C NE/4 NE/4 16 T145N R88W & 24-Aug-00 & Apr-02 \\
\hline Thomas Jefferson State 36-3 & $43.05322 \mathrm{~N}$ & $105.79355 \mathrm{~W}$ & NE/4 NE/4 Sec 36 T36N R75W & 7-Sep-00 & Mar-02 \\
\hline BCX-9 & $41.80364 \mathrm{~N}$ & $108.70250 \mathrm{~W}$ & $\mathrm{SW} / 4 \mathrm{NW} / 4 \mathrm{Sec} 11 \mathrm{~T} 21 \mathrm{~N}$ R100W & 24-Oct-00 & Apr-02 \\
\hline PNG Duvall 13J-D & $44.04874 \mathrm{~N}$ & $105.45364 \mathrm{~W}$ & NW/4 SE/4 Sec 13 T47N R72W & 10-Jun-01 & Mar-02 \\
\hline KU Harriett 41-34-4777 & $44.00798 \mathrm{~N}$ & $106.09271 \mathrm{~W}$ & NE/4 NE/4 Sec 34 T47N R77W & 13-Jun-01 & Feb-02 \\
\hline PNG Carter-Federal 18F-D & $44.05166 \mathrm{~N}$ & $105.56000 \mathrm{~W}$ & $\mathrm{SE} / 4 \mathrm{NW} / 4 \mathrm{Sec} 18 \mathrm{~T} 47 \mathrm{~N}$ R72W & 21-Jul-01 & Feb-02 \\
\hline Remington 587930 07A & $44.97265 \mathrm{~N}$ & $106.42874 \mathrm{~W}$ & SW/4 NE/4 Sec 30 T58N R79W & 5-Dec-01 & May-02 \\
\hline Remington $57-79-18-03 R$ & $44.91805 \mathrm{~N}$ & $106.43215 \mathrm{~W}$ & NE/4 NW/4 Sec 18 T57N R79W & 8-Dec-01 & May-02 \\
\hline Remington $58793001 \mathrm{C}$ & $44.97623 \mathrm{~N}$ & $106.42377 \mathrm{~W}$ & NE/4 NE/4 Sec 30 T58N R79W & 8-Dec-01 & May-02 \\
\hline Bullwacker Creek Unit (BCU) 32-9-4277 & $43.62830 \mathrm{~N}$ & $106.11680 \mathrm{~W}$ & SW/4 NE/4 Sec 9 T42N R77W & 18-Jan-02 & Jan-03 \\
\hline Whiskey Draw Unit 12-12-4778 & $44.06227 \mathrm{~N}$ & $106.18863 \mathrm{~W}$ & $\mathrm{SW} / 4 \mathrm{NW} / 4 \mathrm{Sec} 12 \mathrm{~T} 47 \mathrm{~N}$ R77W & 8-Jan-03 & Jul-03 \\
\hline McBeth 12-30-4673-BG & $43.93458 \mathrm{~N}$ & $105.68611 \mathrm{~W}$ & $\mathrm{SW} / 4 \mathrm{NW} / 4 \mathrm{Sec} 30 \mathrm{~T} 46 \mathrm{~N}$ R73W & 22-Apr-03 & Sep-03 \\
\hline State $23-16-4171$ & $43.52525 \mathrm{~N}$ & $105.39694 \mathrm{~W}$ & NE/4 SW/4 Sec 16 T41N R71W & 9-Jul-03 & Jan-03 \\
\hline Groves 12-19-4574 & $43.86103 \mathrm{~N}$ & $105.80693 \mathrm{~W}$ & SW/4 NW/4 Sec 19 T45N R74W & 22-Oct-03 & May-04 \\
\hline PNG 24-1 & $43.51627 \mathrm{~N}$ & $105.33530 \mathrm{~W}$ & SE/4 SW/4 Sec 24 T41N R71W & 25 -Oct-03 & Jan-04 \\
\hline PNG 26-1 & $43.57958 \mathrm{~N}$ & $105.34513 \mathrm{~W}$ & $\mathrm{SE} / 4 \mathrm{SE} / 4 \mathrm{Sec} 26 \mathrm{~T} 42 \mathrm{~N}$ R71W & 28-Oct-03 & Jan-04 \\
\hline State $21-16-4775 \mathrm{~W}$ & $44.05422 \mathrm{~N}$ & $105.88392 \mathrm{~W}$ & NE/4 NW/4 Sec 16 T47N R75W & 8-Jun-04 & Sep-04 \\
\hline State $21-16-4775 B G$ & $44.05442 \mathrm{~N}$ & $105.88394 \mathrm{~W}$ & NE/4 NW/4 Sec 16 T47N R75W & 10-Jun-04 & Sep-04 \\
\hline PNG Rawhide CBM 1 & $44.43386 \mathrm{~N}$ & $105.56014 \mathrm{~W}$ & NE/4 NW/4 Sec 6 T51N R72W & 28-Jul-04 & Sep-04 \\
\hline Ilo Ridge 1 & $43.92367 \mathrm{~N}$ & $108.52209 \mathrm{~W}$ & NE/4 SW/4 Sec 29 T46N R97W & $15-O c t-04$ & Sep-04 \\
\hline
\end{tabular}




\section{Collection and Analyses of New Data}

Technical data were collected by coring coal beds (fig. 2) from 41drill holes in the PRB, WB, BHB, and GRB, including areas adjoining coal mines (see fig. 1). Analyses include methane desorption and adsorption analysis (which are contained in this report) and gas composition, coal quality, and coal petrology. These coal analyses, along with chemical analyses of coal-seam water, will be published later. Thirty-six wells were drilled and cored in the PRB, one in the BHB, and one in the GRB to collect new data from potential coal-bed reservoirs in CBM units on Federal lands managed by BLM's Buffalo, Rawlins, Rock Springs, and Worland field offices (fig. 1). Three wells were drilled and cored in the WB, North Dakota (fig. 1).

\section{Data to be Reported}

This report presents data (including tables and appendices) on: (1) cooperating gas operators, corehole designation, and location of corehole (tables 1a and 1b); (2) canister position and number, canister depth (Appendix I); (3) coal bed name as supplied by the operator (Appendices I and II); (4) lost, measured, residual, and total gas (Appendix II); (5) moisture and ash yield (Appendix II); and (6) adsorption isotherms and Langmuir volume and pressure parameters (Appendix III). The coal-bed nomenclature used in this report includes some informal names used by gas operators that do not necessarily follow those accepted formally by the USGS in the PRB. For example, names used by most gas operators such as Big George and

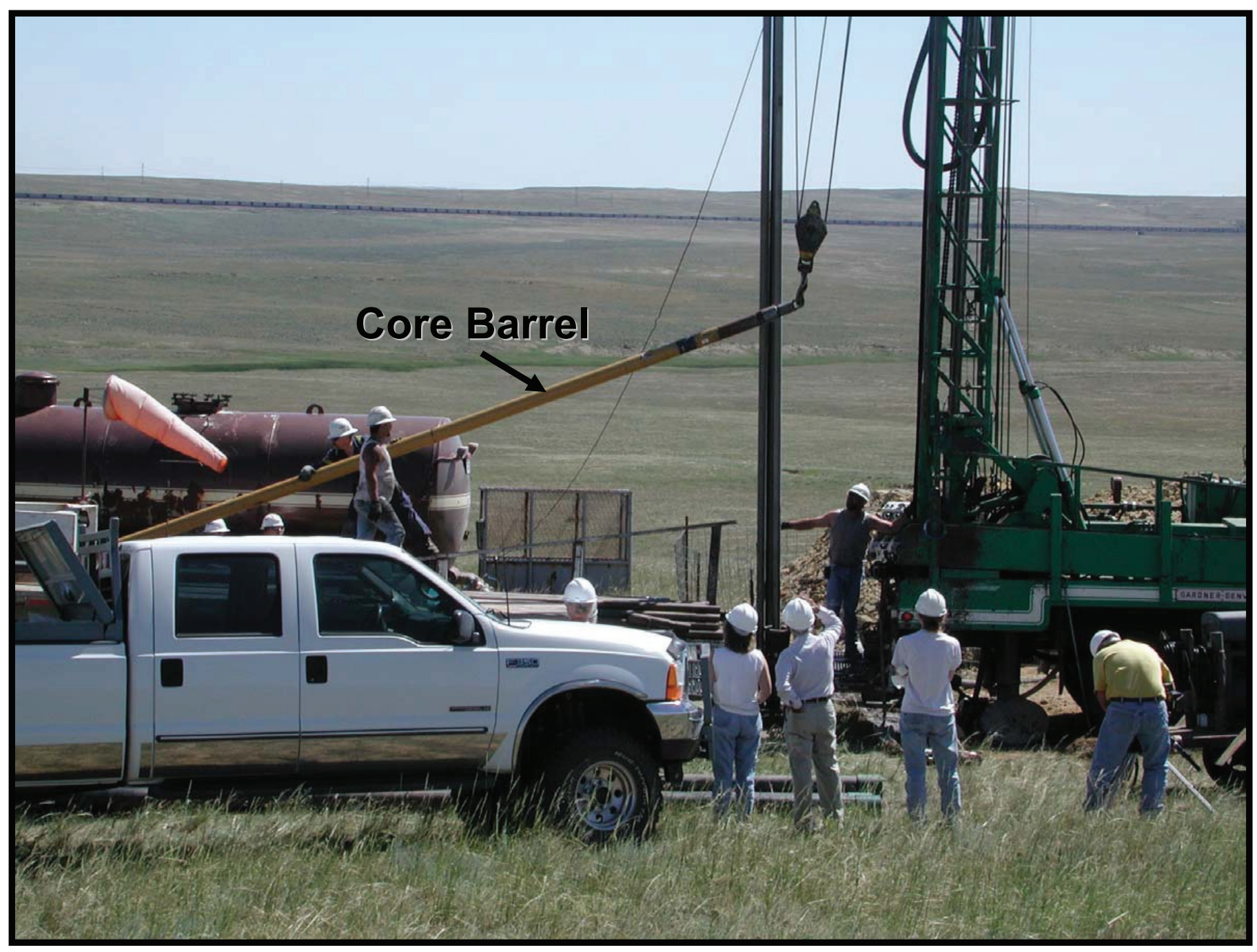

Figure 2. Drill site showing drilling rig and 30-ft core barrel for collecting coal cores from a Peabody Natural Gas CBM well in the Powder River Basin, Wyoming. 
Wyodak coal beds, are called Anderson and Canyon coal beds, respectively, by the USGS. Although gas operators generally follow USGS coal bed nomenclature in the PRB, either by design or accident (fig. 3), the use of these names in this report does not imply endorsement by the USGS.

\section{Background Information}

Since 1957, it has been well known that Fort Union Formation coals in the PRB contain methane; a number of shallow (depth 245 to $415 \mathrm{ft}$ ) flowing artesian water wells investigated by the USGS, for example, were reported to contain substantial amounts (Olive, 1957; Lowry and Cummings, 1966; and Whitcomb and others, 1966). Hobbs (1978) and Boreck and Weaver (1984) presented gas content and chemical data. Hobbs (1978) measured 8-9 standard cubic feet/ton (scf/t) of gas from two coal samples collected from 15 shallow drill holes (about 400-500 ft deep) that penetrated the Wyodak-Anderson coal zone (including the Smith, Anderson, and Canyon coal beds) in the Recluse area of northeastern Campbell County and south of Gillette, Wyoming (fig. 1). Methane was encountered not only in these coal beds, but also in the overlying sandstone beds and interbedded sandstone, siltstone, and shale beds. Gas flow rates varied from a trace in shale interbeds to between 900 thousand cubic feet (MCF) to 1 million cubic feet (MMCF) per day in the sandstones. Hobbs (1978) suggested that there was potential methane production from the Anderson and Canyon coal beds, from fluvial channel sandstones between the coal beds, and possibly from strata below the Canyon coal.

Coalbed methane development from Fort Union Formation subbituminous coals in the PRB, Wyoming and Montana (fig. 1), started with two wells south of Gillette, Wyoming that produced more than $200 \mathrm{MCF}$ in 1981. These wells, about 550 to $700 \mathrm{ft}$ deep, were completed in the Wyodak-Anderson coal bed. Since 1981, total CBM production has steadily risen to about 1.8 trillion cubic feet (TCF) as of December 2005 in the Wyoming part of the basin, with production approaching 30 billion cubic feet $(\mathrm{BCF})$ per month. It is anticipated that more than 60,000 producing wells will be completed in the Wyoming part of the PRB and more than 10,000 producing wells in the Montana part. This rapid rate of development is mainly driven by the low cost of drilling shallow wells (less than 2,000 ft deep). Additionally, current resource estimates indicate that there are more than 1 trillion short tons of coal (Crockett and others, 2001; Fort Union Coal Assessment Team, 1999) distributed basinwide at depths of 100 to 3,500 $\mathrm{ft}$. This amount of coal has led to an estimated in-place CBM resources of 30 TCF by Rice and Finn (1996), 26 TCF by Finley and Goolsby (2000), and 23 TCF by Crockett (2002). More recently, Flores (2004) estimated undiscovered CBM resources at 12.1 TCF for the upper part of the Fort Union Formation in the PRB in the next $30 \mathrm{yr}$, based on the total petroleum system model and extrapolation of production figures for 1,500 wells as of 1999, as well as the expected potential for additions to reserves during that time. More than 28,000 wells have been permitted, drilled, or completed as of December 2005; of this total, 17,000 wells (61 percent) are producing CBM.

\section{Methods}

Members of the CBM cooperative project collected data from 41 CBM wells (fig. 1, table 1a) that were continuously cored in the Mesaverde and Fort Union Formations. Coal beds in the PRB include Wyodak-Anderson coal zone (see Fort Union Coal Assessment Team, 1999, for coal beds within this zone), Cook, Wall, Pawnee, and School. The 41 recovered coal cores (fig. 4) required the use of 615 2-ft-long canisters (fig. 5) for desorption, resulting in a like amount of gas-content determinations. One-kilogram samples of the most and least gassy coal cores from each well were collected for adsorption (isotherm) analyses resulting in 75 isotherm values that were assigned canister numbers (Appendix I; a few analyses do not have canister numbers and are grab samples collected in the field and these were not desorbed). These analyses, performed by R.M.B. Earth Science Consultants Ltd., determined the gas storage capacity of the coal and amount of pressure required to reach critical desorption pressure at a constant temperature, generally the reservoir temperature. The high-pressure methane gas adsorption analyses were determined using a high-pressure volumetric adsorption technique similar to that described by Mavor and others (1990).

The gas content was determined from the desorption of gas (generally methane) from the coal using the methods described by Diamond and Schatzel (1998). Coal cores were desorbed and the amount of desorbed gas measured every 15 min for the first $9 \mathrm{~h}$ after the canisters were sealed (fig. 6). The following were recorded for each measurement: (1) time, (2) ambient temperature (atmospheric), (3) barometric pressure (atmospheric), (4) internal temperature of the canister, and (5) volume of gas released from the coal in the canister. The desorbed gas values recorded during this 9-h interval were used to estimate lost gas, which is defined as the volume of gas desorbed from the coal from the moment the coal was cored until sealed in a canister. After this $9 \mathrm{~h}$ recording period, the canisters were measured for desorbed gas and recorded at intervals of $30 \mathrm{~min}, 1 \mathrm{~h}, 3 \mathrm{~h}$, and $6 \mathrm{~h}$, depending upon the gassiness of the coal. This desorption process took place on-site in a CBM wet laboratory (provided by the RMG in Casper, Wyoming; see fig. 7). After the canisters had desorbed sufficient gas, they were then ready for transport to the USGS laboratory facilities in Denver, Colorado. In Denver, additional measurements of desorbed gas were progressively performed daily, every few days, and weekly until the coal in the canisters was completely desorbed. All gas volumes are reported in standard cubic feet per short ton ( $\mathrm{scf} / \mathrm{t})$; a standard cubic foot of gas is defined as a cubic foot of gas reported at standard temperature and pressure, which is $60^{\circ} \mathrm{F}$ and 14.696 pounds per square inch absolute (psia). Previous workers (McCulloch 


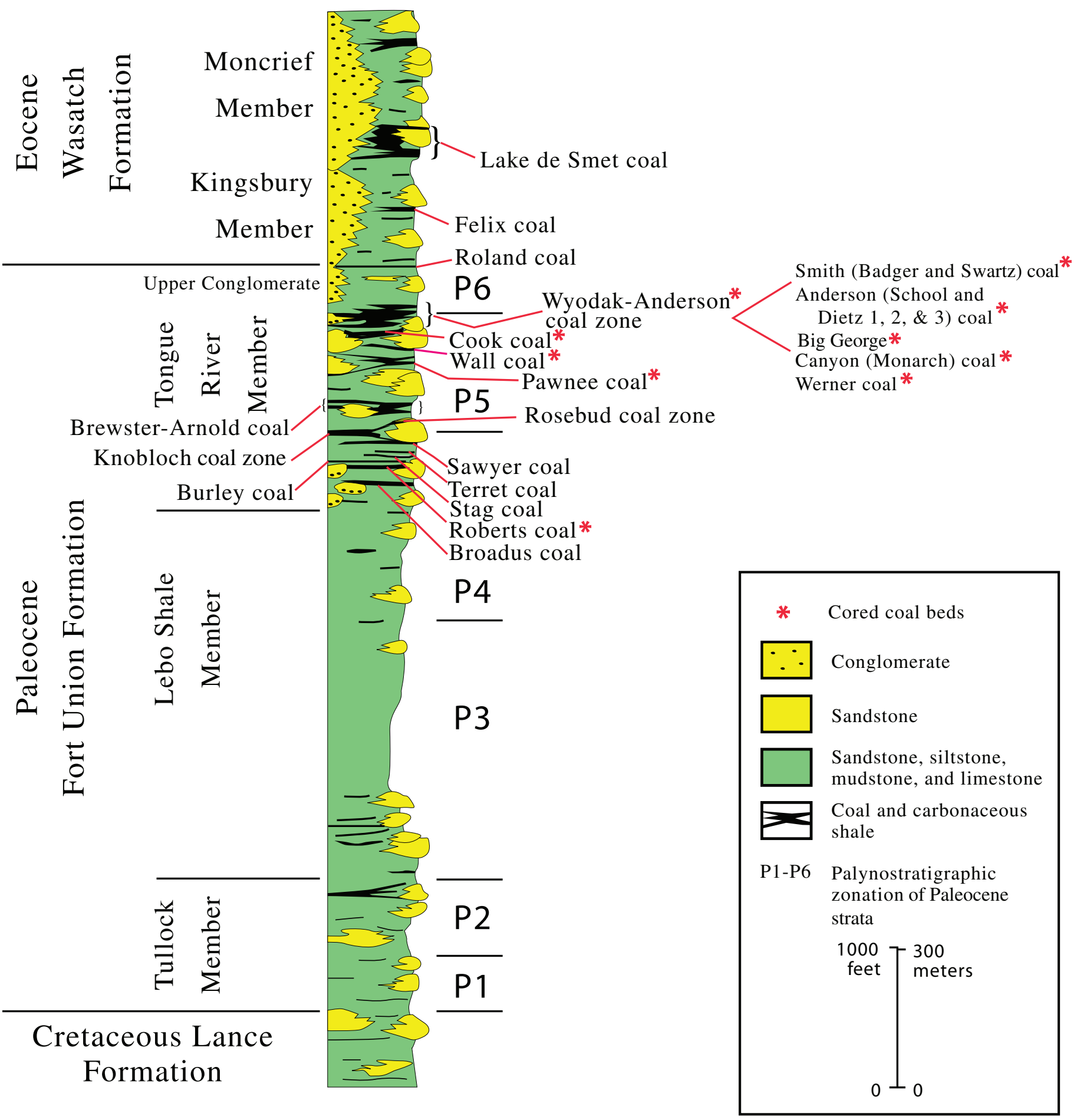

Figure 3. Stratigraphic column of the Fort Union Formation in the Powder River Basin, Wyoming and Montana. Palynostratigraphic zonation of Paleocene strata taken from Nichols (1994). 

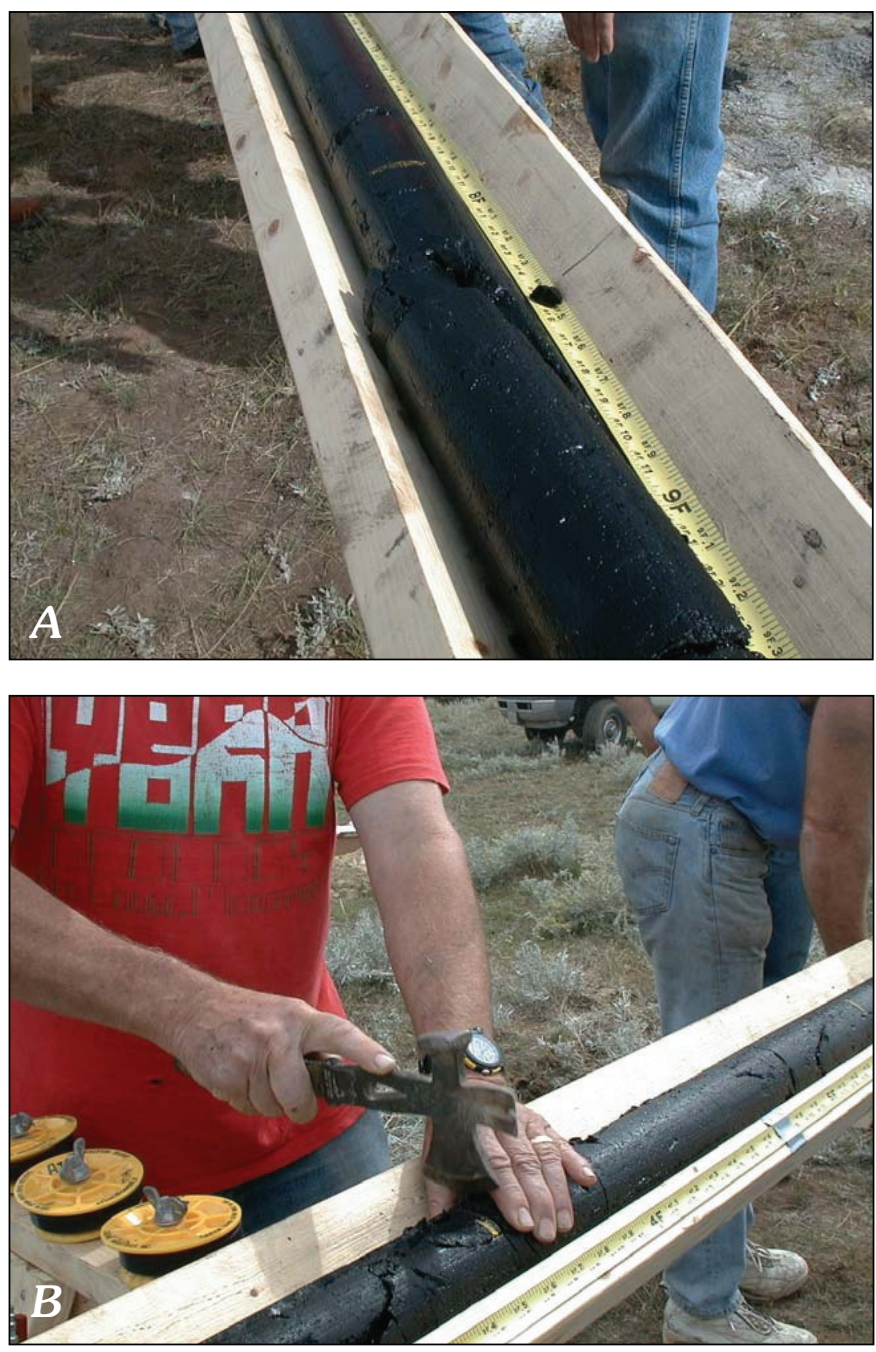

Figure 4. Photograph showing measurement of a continuous core $(A)$ and cutting the core $(B)$ of a Fort Union coal bed in the Powder River Basin, Wyoming.

and others, 1975) suggested an arbitrary desorption rate of $1.06 \mathrm{scf} / \mathrm{t}$ per day (in their terms, 0.05 cubic centimeters per gram per day) for one week. For our study, we used an arbitrary termination desorption rate value for all canisters of 0.01 scf/t per day; complete desorption took as long as 4 months to reach that arbitrary desorption rate termination value. When the coalbed gas was completely desorbed, each canister was weighed and filled with distilled water and re-weighed.

The above measurements, plus the weight and volume of the empty canisters, were used to calculate coal weight and volume and headspace volume of the coal in each canister. These measurements, plus the data collected on-site and in the USGS laboratory, in turn, were used in the final calculations of the gas content in scf/t of coal. The calculations utilize the U.S. Bureau of Mines Direct Method determination of gas content, which was developed originally to estimate the
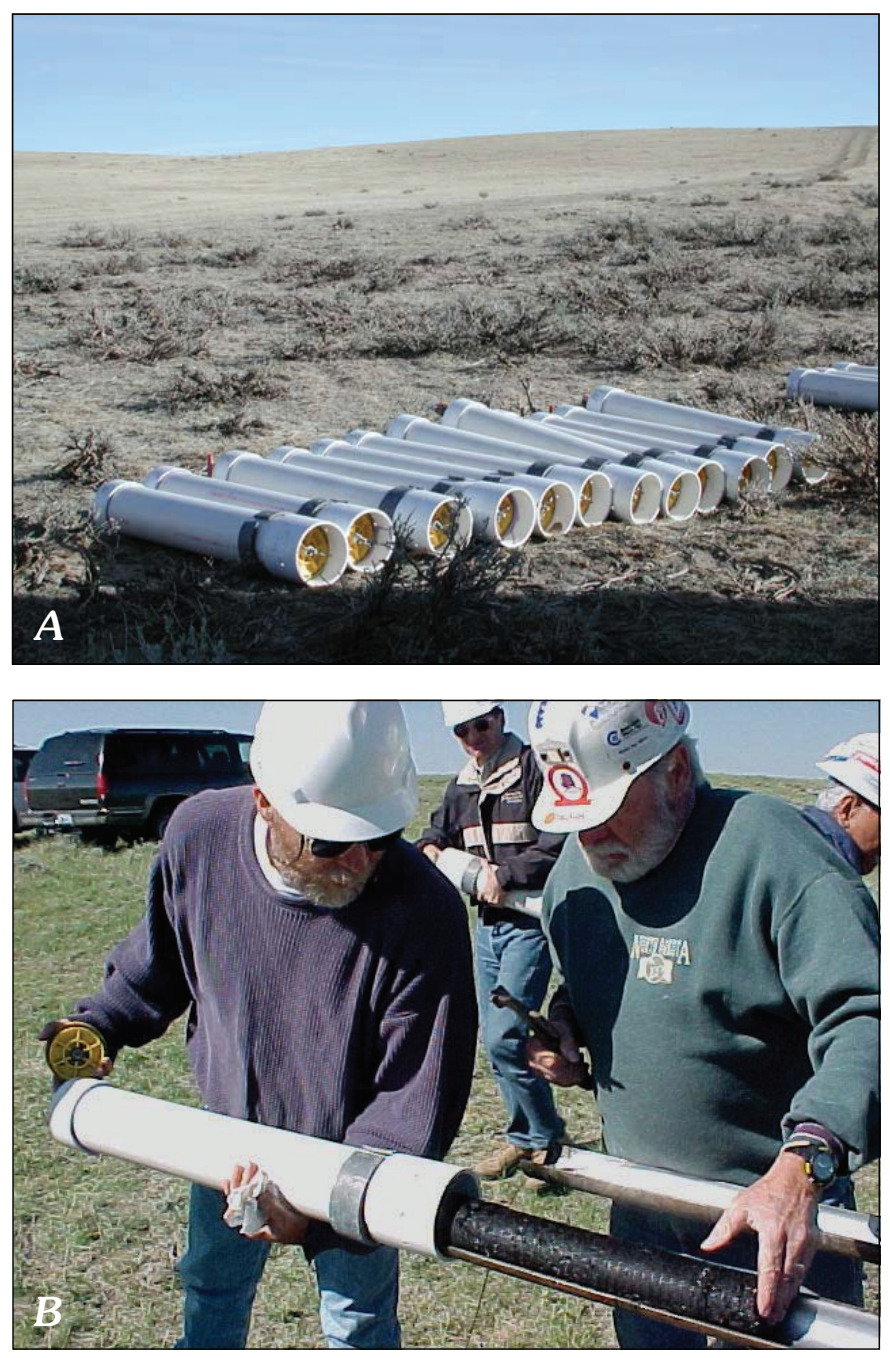

Figure 5. Photographs of the 2-ft long, airtight canisters $(A)$ used to collect coal cores $(B)$ for gas desorption measurements.

gas content of coals to be mined underground (Diamond and Levine, 1981, as described in Mavor and Nelson, 1997) and provide the most accurate estimate of lost gas volume compared to other methods (for example, the Smith and Williams and Amoco methods as described in Mavor and Nelson, 1997). Thus, the total gas content (scf/t) for each canister was estimated by summing (1) the lost gas content as determined using the Direct Method divided by the coal mass, (2) the measured gas content (gas volume released from the coal sample while the coal was sealed in a canister) divided by the coal mass, and (3) the residual gas content (volume of gas remaining in the coal sample at the end of canister desorption interval) divided by the coal mass. The USGS estimated that the residual gas content for Fort Union Formation coals in the Wyoming part of the Powder River Basin coals is approximately 2.5 percent of the total gas content. 

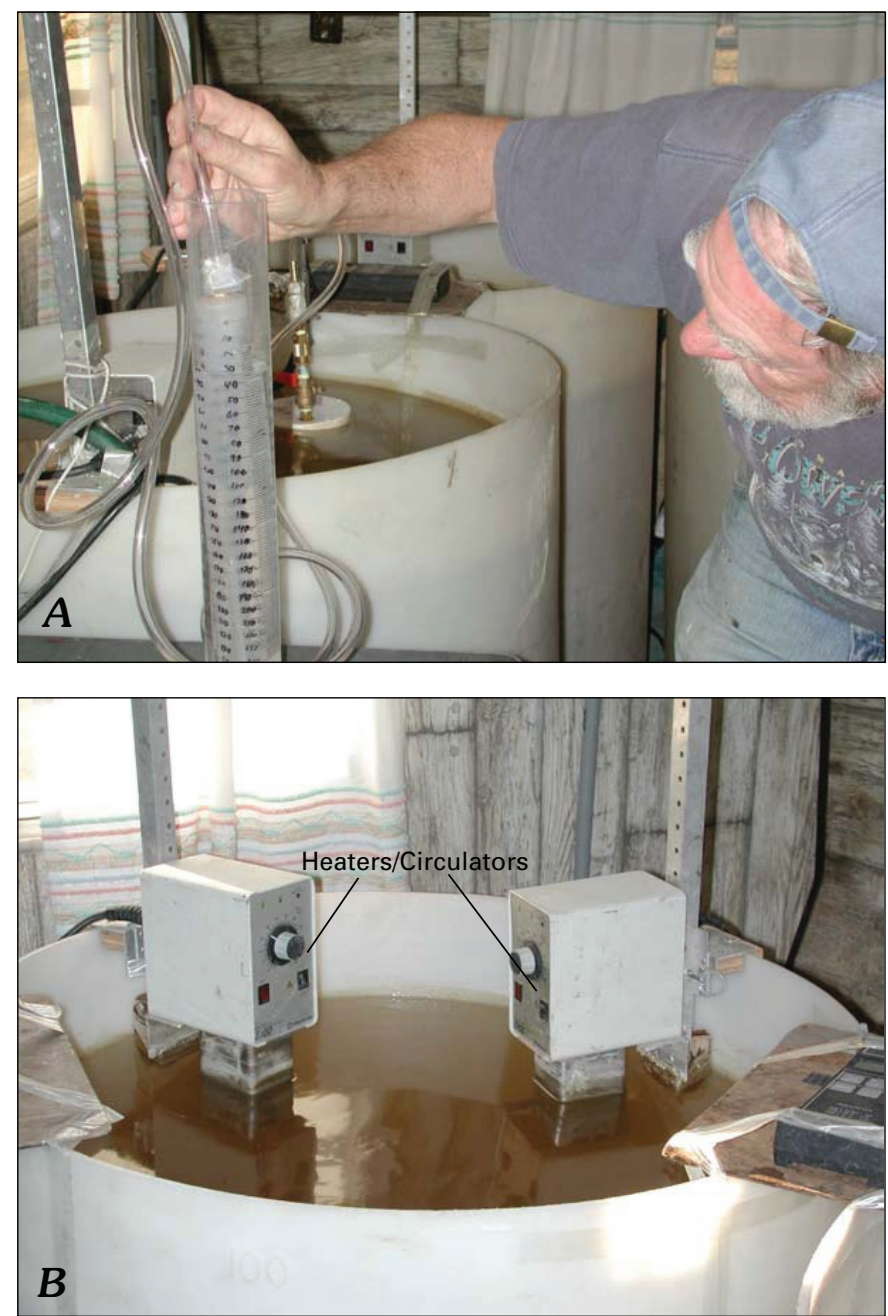

Figure 6. Photographs showing desorption of gas using a graduated cylinder $(A)$ and heated water baths used to maintain reservoir temperature $(B)$.

\section{Discussion of Data and Results}

The data collected from the coal cores included results from gas desorption and adsorption isotherm analyses. A total of more than $1,700 \mathrm{ft}$ of cores were collected for gas desorption study, with each well containing either a continuous core of the entire coal bed or partial cores of the coal bed (see core holes 1-37, Appendix I). The continuous core includes as many as 51 canisters from a 105-ft thick coal bed (for example, Barrett Resources Corporation's KU Harriet 41-34-4477 core hole; see core hole 26, Appendix I) or as few as 2 cores in a 60-ft thick coal bed (for example, Ocean Energy Inc.'s Schlautmann 9-10-45-74WY [43-10C]; see core hole 3, Appendix I). The stratigraphic positions of the cores in the coal beds were verified by gamma ray or density logs for accuracy (see Appendix I), however, few wells do not have geophysical logs (such as, Gregory Water and Energy, Inc.'s Leroy Gregory 1; see core
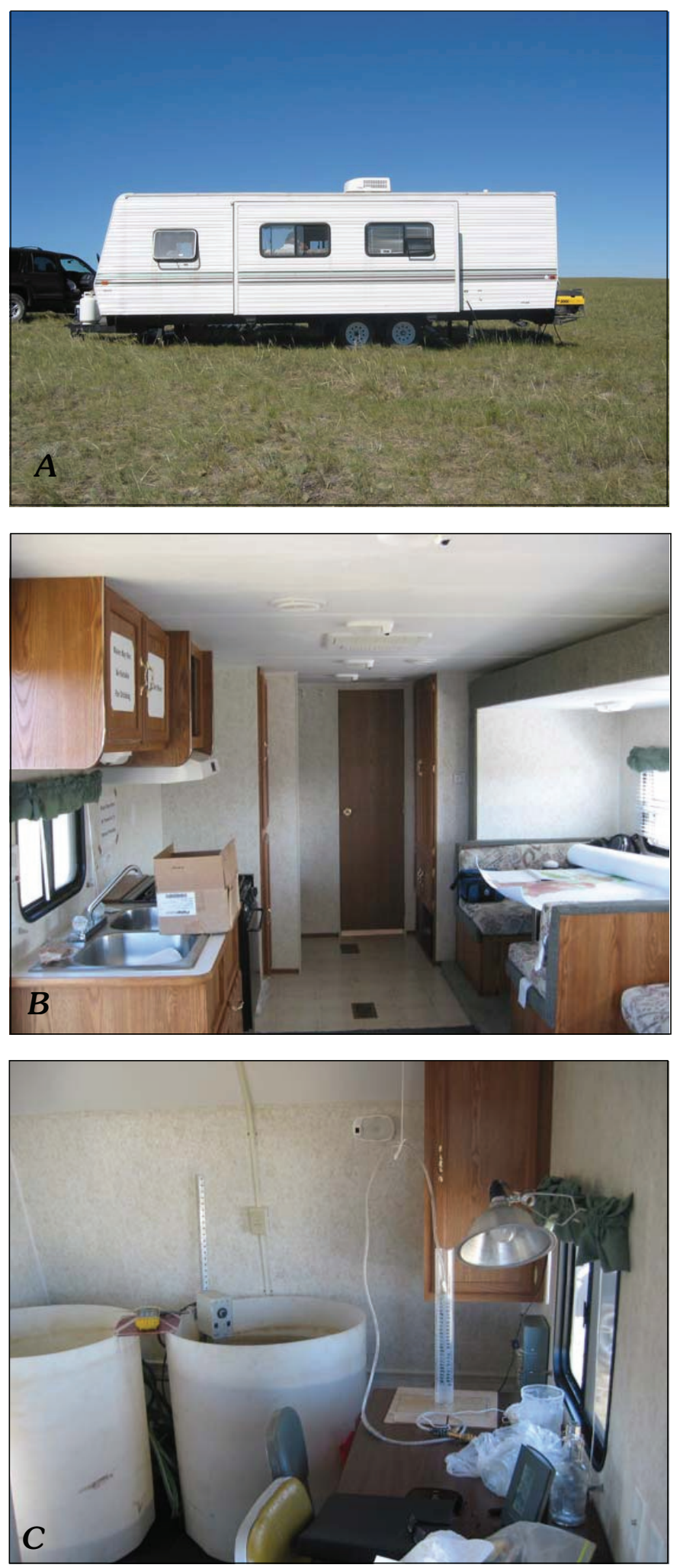

Figure 7. Photographs showing a trailer $(A)$ converted into a mobile field office $(B)$ and wet laboratory $(C)$ with water baths and gas desorption apparatus. 
hole 7, Appendix I). Continuous coal bed coring was attempted in each well, but 100-percent recovery, which was not attained in many of the core holes, depended on the type core barrel used (split versus plastic liner), the quality of the coring crews, and the physical characteristics of the coal.

\section{Gas Desorption Data}

The gas desorption data for each well in the PRB, GRB, and WB are summarized in Appendix II. Perusal of the data indicates that the total gas content of coals varies: (1) within the same coal bed, (2) between different coal beds, (3) according to geographic distribution of coal beds, and (4) with depths of coal beds.

\section{Powder River Basin}

\section{Gas Variations Within and Between the Same Coal Bed}

Vertical variation of the total gas content in a coal bed is illustrated by analyses of continuous cores of the Big George coal bed recovered from the MichiWest Energy Pilot State 16-32 well (fig. 1; core hole 2, Appendices I and II), which show the total gas content to vary from as low as $35.01 \mathrm{scf} / \mathrm{t}$ in the lowermost part of the bed to as much as $90.52 \mathrm{scf} / \mathrm{t}$ in the uppermost part of the bed. The horizontal variation in gas content in the Big George coal bed is also well illustrated by comparisons between that well and the MichiWest Energy Pilot 16-14 well (core hole 1, Appendix II), located at a distance of 2,867 ft. In the MichiWest Energy Pilot 16-14, the total gas content of the Big George is as low as $16.82 \mathrm{scf} / \mathrm{t}$ in the uppermost part of the bed and as much as $77.45 \mathrm{scf} / \mathrm{t}$ in the middle part of the bed. The variations in gas content may in part be due to high ash yield. A study of the coal composition (for example, macerals) of coal bed samples from the same well by Chiehowsky and others (2003) indicated that the woody macerals contain more gas and the fusain contains less.

\section{Gas Variations Between Stratigraphically Different Coal Beds}

Variations of two stratigraphically different coal beds in the same core hole are exemplified by the Barrett Resources Corporation Haas 32-31 well (core hole 5, Appendices I and II), in which the Big George coal bed is about $290 \mathrm{ft}$ above the Wyodak coal bed. The Big George coal bed contains total gas as low as $13.66 \mathrm{scf} / \mathrm{t}$ in the uppermost part and as much as $16.85 \mathrm{scf} / \mathrm{t}$ in the lowermost part. In comparison, the Wyodak coal bed contains total gas as low as $22.95 \mathrm{scf} / \mathrm{t}$ in the middle part and as much as $33.32 \mathrm{scf} / \mathrm{t}$ in the upper part. The low total gas content may be due to high ash yield, which is as much as 20.15 percent on an as-received basis. Thus, the deeper Wyodak coal bed contains more gas than the shallower Big George coal bed.
Gas variations for coal beds that are stratigraphically lower in the Tongue River Member of the Fort Union Formation than the Big George and Wyodak coal beds (Flores, 2004; Flores and others, 2005), are exemplified by the Pennaco Energy Sorenson 2-33-54-74W well (core hole 4, Appendix II). This well penetrated the Cook coal bed in the depth interval 815-836 ft and the Wall coal bed in the depth interval 1,141-1,186 ft. The Cook coal bed contains total gas as low as $0.88 \mathrm{scf} / \mathrm{t}$ in the lowermost part and as much as $22.74 \mathrm{scf} / \mathrm{t}$ in the upper part. The low gas content is directly related to the high ash yield, which is as much as 67.54 percent on an as-received basis. The Wall coal bed contains total gas as low as $28.95 \mathrm{scf} / \mathrm{t}$ in the upper part and as much as $37.40 \mathrm{scf} / \mathrm{t}$ in the lower part of the bed. The low gas content is due to high ash yield, which, except for one canister, is as much as 7.47 percent on an as-received basis: canister B1, which contains total gas of $35.23 \mathrm{scf} / \mathrm{t}$, has the highest ash yield of 13.62 percent on an as-received basis (core hole 4, Appendix II). The deeper Wall coal bed contains more total gas than the shallow Cook coal bed.

\section{Geographic Variations}

The CMS Energy West 6-19W well, which penetrated the Canyon, Cook, and Wall coal beds (core hole 6, Appendix I), is approximately $25 \mathrm{mi}$ northwest of the Pennaco Energy Sorenson 2-33-54-74W well (core hole 4, Appendix II); the Cook and Wall coal beds may correlate between the two wells. The Cook coal bed in the CMS Energy West 6-19W well is in the depth interval 944-960 ft and the Wall coal is in the depth interval 1,070-1,078 ft. The Cook coal bed contains total gas as low as $26.01 \mathrm{scf} / \mathrm{t}$ in the upper part and as much as $39.56 \mathrm{scf} / \mathrm{t}$ in the lower part. The Wall coal bed contains total gas as low as $28.36 \mathrm{scf} / \mathrm{t}$ at the base and as much as 36.72 $\mathrm{scf} / \mathrm{t}$ in the top part. Comparison of the total gas content of the Wall coal bed in the two wells indicates little lateral change, whereas the total gas content of the Cook coal bed in CMS Energy West 6-19W well is lower by 30 percent.

The CMS Energy Laramore 11-6C well (core hole 8, Appendix II) penetrated the Smith, Anderson, Canyon, and Cook coal beds in the depth intervals $343-386 \mathrm{ft}, 779-791 \mathrm{ft}$, 986-994 ft, and 1,340-1,350 ft, respectively. The uppermost part of the Smith coal bed has a total gas content of 16.99 scf/t and an ash yield of 16.54 percent on an as-received basis; the total gas content of the rest of the Smith coal bed ranges from $18.97 \mathrm{scf} / \mathrm{t}$ to $26.70 \mathrm{scf} / \mathrm{t}$. Total gas contents range from 28.73 to $32.42 \mathrm{scf} / \mathrm{t}$ in the Anderson coal bed and 33.83 to $68.87 \mathrm{scf} / \mathrm{t}$ in the Cook coal bed; ash yield in the latter bed is as much as 48.44 percent.

\section{Depths of Coal Beds}

The Roberts coal bed in the Nance Petroleum Remington 587918 03R well (core hole 29, Appendix II) was the deepest coal bed (depth 2,190-2,204 ft) that was studied. Total gas content in this bed ranges from a low of $72.41 \mathrm{scf} / \mathrm{t}$ with ash 
yield of 38.58 percent on an as-received basis to a high of $114.46 \mathrm{scf} / \mathrm{t}$, which is the highest of all those analyzed; ash yield is 4.80 percent on an as-received basis. However, other deep $(1,176$ and 1,276 ft) coal beds such as the Pawnee coal bed penetrated at the Peabody Natural Gas (PNG) 24-1 and 26-1 wells had low total gas content ranging from 1.67-6.16 scf/t (core holes 36, 37, Appendix II).

In contrast, at shallow depths along the eastern margin of the Powder River Basin the lowest recorded total gas content was for the Wyodak in the Peabody Natural Gas wells (PNG 34-1, PNG 33-1, PNG 31-1, and PNG 35-1; core holes 15, 16, 17, 18, Appendix II). These wells, located about 1-3 miles from the highwalls of the North Rochelle and Rochelle coal mines, penetrated this bed at depths ranging from 258 to $407 \mathrm{ft}$. In the PNG 34-1 well, which is closest to the coal mine, total gas contents are $0.48 \mathrm{scf} / \mathrm{t}$ in the upper part and as much as $1.77 \mathrm{scf} / \mathrm{t}$ in the lower part. In the PNG 35-1 well located farthest from the coal mine, total gas content is as low as $11.7 \mathrm{scf} / \mathrm{t}$ in the upper part and as much as $17.2 \mathrm{scf} / \mathrm{t}$ at the middle part.

A similar trend of low gas contents was observed between the PNG 16-2 well (core hole 20, Appendix II), which is close to the Caballo coal mine, and the Rim Operating CBM H 11-04 and CBM C 33-1R wells (core holes 13, 14, Appendix II), which are about 500-1,000 ft from the highwall of the Jacob Ranch coal mines. The PNG 16-2 well penetrated the Wyodak coal bed from 213-283 ft and has a total gas content as low as $3.67 \mathrm{scf} / \mathrm{t}$ in the upper part and as high 12.5 $\mathrm{scf} / \mathrm{t}$ in the lower part. The Rim Operating (CBM H 11-04) well penetrated the bed from 204 to $280 \mathrm{ft}$, where it has total gas contents as low as $1.20 \mathrm{scf} / \mathrm{t}$ in the middle part and as high as $14.59 \mathrm{scf} / \mathrm{t}$ in the lower part. In the CBM C 33-1R well, which is approximately $2.5 \mathrm{mi}$ west of CBM H 11-04, Wyodak coal bed at depths ranging from 259 to $319 \mathrm{ft}$ has a total gas content as low as $8.22 \mathrm{scf} / \mathrm{t}$ in the upper part and as high as $15.4 \mathrm{scf} / \mathrm{t}$ in the middle part.

\section{Other Basins}

Gas desorption data from subbituminous coal in the Fort Union Formation in the GRB and from lignite in the Fort Union Formation in the WB are summarized in Appendix II (see data for core holes 7, 21, 22, 24). Gas desorption data from the BHB are not available for release until the end of 2006 per our agreement with the operators (see Introduction).

\section{Williston Basin}

The three wells cored in the Williston Basin (fig. 1) are Gregory Water and Energy, Inc. Leroy Gregory 1 and The Coteau Properties MC00250C and MC00251 (core holes 7, 21, 22, Appendix II). An unnamed coal bed in the Gregory Water and Energy, Inc. Well was penetrated in the depth interval 934-957 ft, and contained a gas content ranging from 0.32 to $1.02 \mathrm{scf} / \mathrm{t}$. In the Coteau Properties well MC 00250C (1) the Buelah coal bed (fig. 8), depth 167-175 ft, had low gas con- tents of 0.57 and $0.88 \mathrm{scf} / \mathrm{t}$; and (2) several unnamed coal beds at depths between 438.2 and $573.4 \mathrm{ft}$ had somewhat higher gas contents, 0.96 to $2.55 \mathrm{scf} / \mathrm{t}$. Coal in the depth interval 788-796 $\mathrm{ft}$ in the MC 00251 well also showed a low gas content of 0.40 to $0.86 \mathrm{scf} / \mathrm{t}$. The ash yield of these lignite coal beds ranges from 5.0 to 41.1 percent on an as-received basis.

\section{Green River Basin}

The total gas content of the Deadman coal bed (fig. 9) ranges from 0.33 to $1.31 \mathrm{scf} / \mathrm{t}$ in the depth interval 943 to 955 $\mathrm{ft}$ in the Bridger Coal Company BCX-9 core hole. This core hole is about 1-2 miles from the Bridger Coal Mine where Deadman coal bed is strip-mined at depths of 100 to $150 \mathrm{ft}$. The ash yield from this coal ranges from 3.23 to 18.10 percent on an as-received basis.

\section{Interpretations of Gas Desorption Results}

The total gas contents of the coalbed gas-producing reservoirs in the PRB vary within and between coal beds, with depth, and with their proximity to the coal mines. The variations are, in part, dependent on ash yield and maceral composition. With few exception, the higher the ash yield the lower the total gas content, indicating that the inorganic matter of the coal is a poor gas absorbent.

Cheihowsky and others (2003) and Moore and others (2001) studied the relation between gas content and maceral composition of the coal beds. The woody banding or lamination of the coal generally adsorbed more gas as shown by the work of Moore and others (2001) (figs. 10-11). These workers have shown that the 90-ft thick Wyodak coal bed in the Peabody Natural Gas 31-1 and 35-1 wells contains as much as 75 percent vitrain banding. The vitrain banding in the coal, which is the same in both wells, generally increases upward and it is mimicked by the total gas content, which also increases upward. In addition, fusain banding or "charcoal" maceral, which is present in the lower part, contains as much gas as the vitrain banding. The high gas content in the vitrain banding probably is due to more surface area to adsorb gas molecules, whereas fusain forms a porous, permeable, and laterally extensive maceral, and probably behaves as a horizontal conduit for gas transport within the coal bed. However, coal beds with ash partings show low gas content.

Cheihowsky and others (2003) studied the relations between total gas content and maceral composition of the 138-ft-thick Big George coal bed in the MichiWest 16-32 well (core hole 2, Appendix I). The total gas content of this coal bed increases upward where woody texture and very coarse laminated attrital layers are common (fig. 12). The lowermost part is dominated by medium- to coarse-laminated attrital layers, as can be interpreted from the gamma ray and density $\operatorname{logs}$ in the depth interval 1,179-1,209 ft (fig. 12). In addition, 

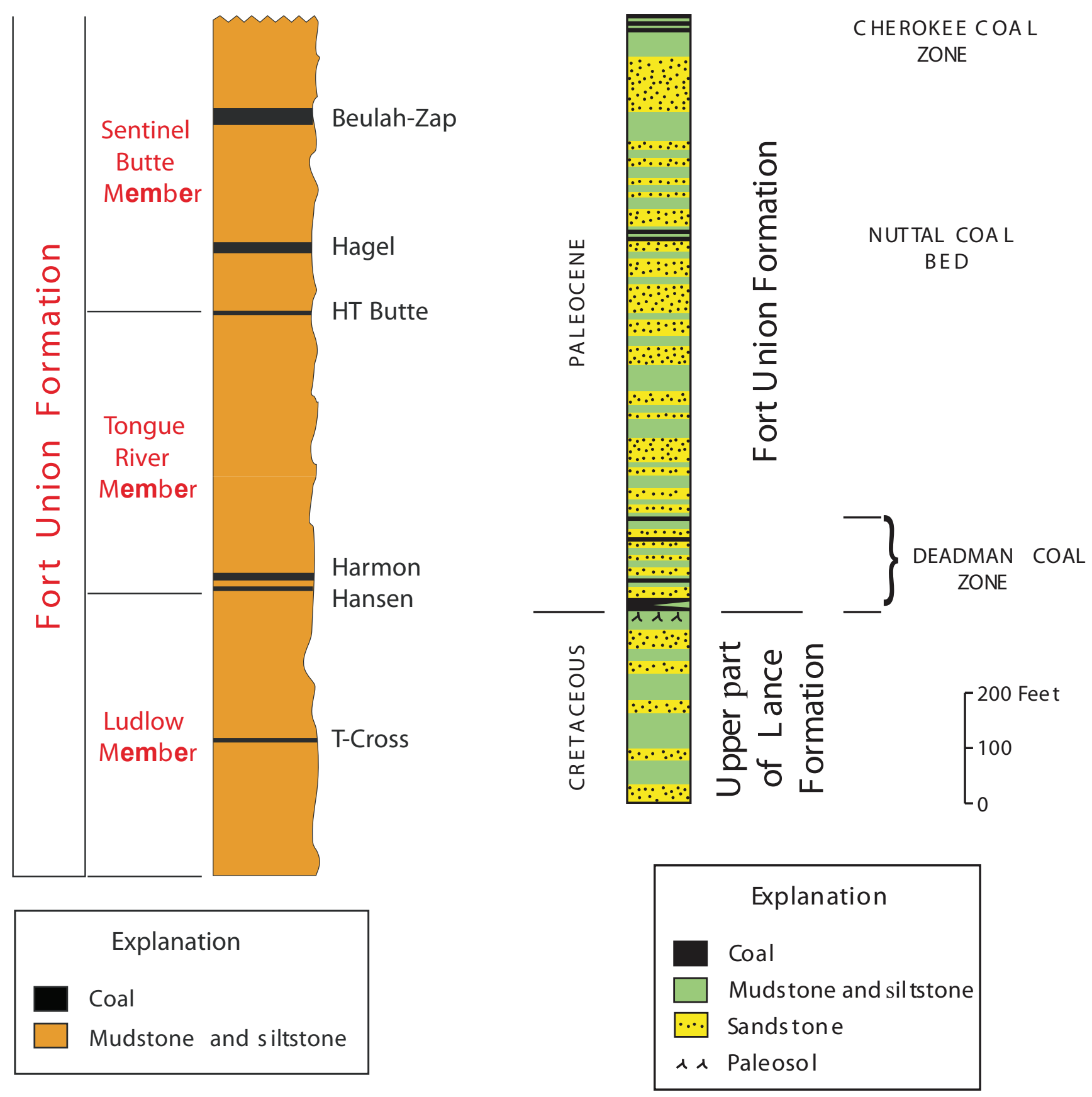

Figure 8. Stratigraphic column showing position of the Beulah coal bed in the Fort Union Formation, Williston Basin, Montana and North and South Dakota.

Figure 9. Stratigraphic column showing position of the Deadman coal bed in the Fort Union Formation, Green River Basin, Wyoming. 


\section{Core PNG 31-1}

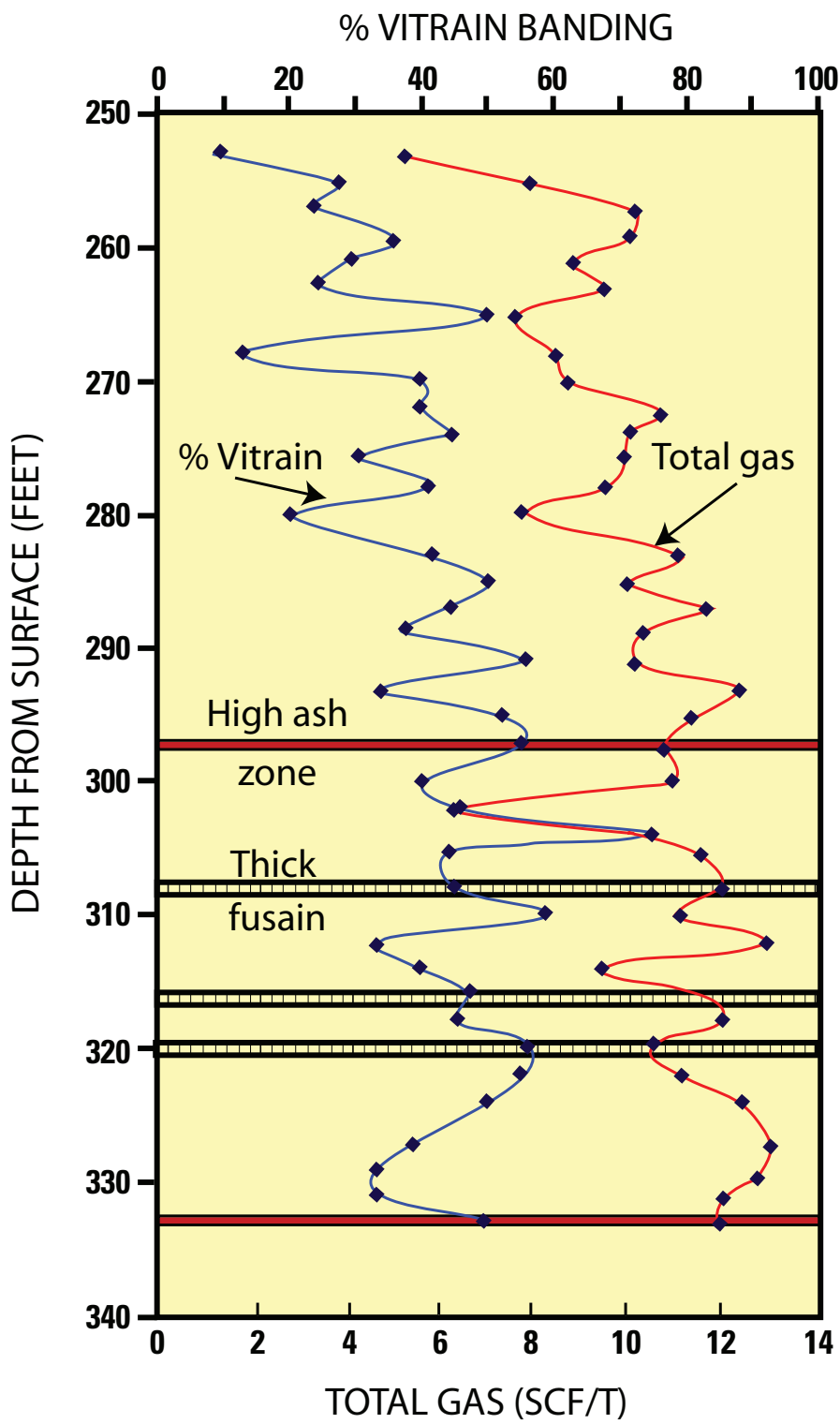

Figure 10. Relations of total gas content with percent vitrain banding in the Peabody Natural Gas 31-1 well. scf/t, standard cubic feet of gas per short ton of coal.

\section{Core PNG 35-1}

$\%$ VITRAIN BANDING

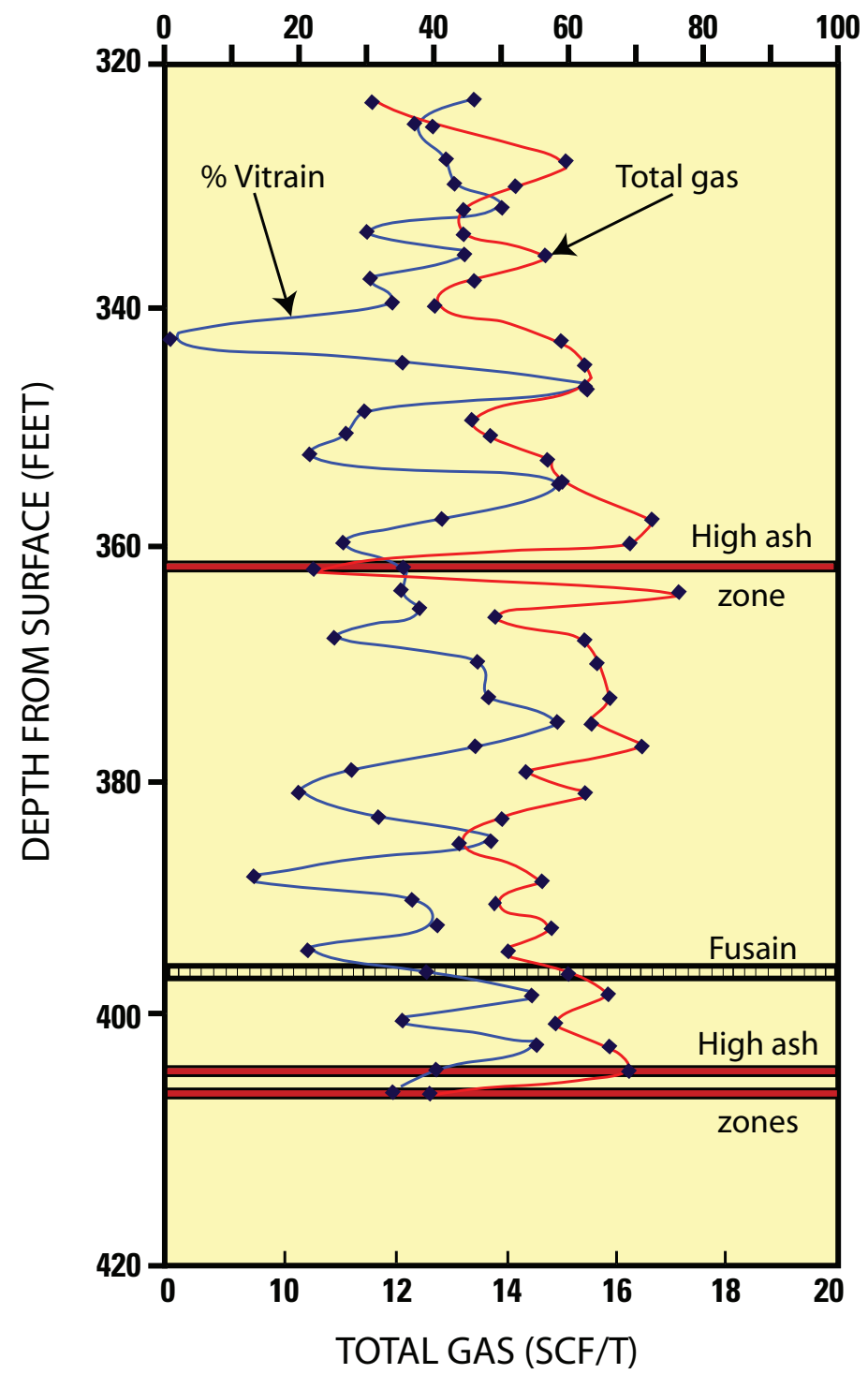

Figure 11. Relations of total gas content with percent vitrain banding in the Peabody Natural Gas 35-1 well. scf/t, standard cubic feet of gas per short ton of coal. 
this part of the coal bed includes interbedded siltstone and sandstone. The relation of the total gas content and the maceral types is best shown in figure 13

Variations of total gas content between coal beds also may be controlled by maceral and inorganic matter compositions. However, the gas content may also be influenced by porosity and permeability. In general, deeper coal beds (for example, the Roberts coal bed), which contain more total gas, may be more porous and permeable due to autocompaction and roof-rock deformation. However, other deep coal beds (for example, Pawnee coal in the Peabody Natural Gas wells: PNG Duvall 13J-D, PNG Carter-Federal 18F-D, PNG 24-1, PNG 26-1; core holes 25, 27, 36, 37 Appendix II) contain low total gas, which may be due to lack of connection of the coal bed to water recharge areas.

The proximity of coal beds to coal mines may have caused gas drainage due to dewatering operations. Dewatering caused lowering of groundwater level and hydrostatic pressure, which in turn, released the gas. Hydrostatic pressure between 1982 and 2004 shows basinward depletion of hydrostatic pressure, causing gas drainage from the pit face to about 3 miles west of the coal mines where there was no significant production as of 2003 (Stricker and Flores, 2003).

The total gas contents of the lignite and subbituminous coals in the other basins is very low. The lignite in the WB contains slightly more total gas than the subbituminous coal beds in the GRB. In general, gas contents in these other basins are not influenced by depth.

\section{Adsorption Isotherm Data}

The adsorption isotherm data, summarized in Appendix III, are given on an as-received, dry with ash, moist ash-free, and dry-ash-free bases for both the adsorbed methane and Langmuir isotherms parameters. The values of Langmuir pressure and volume increase with the absence of ash and moisture for all coal samples. The following discussions focus on comparison of Langmuir isotherms of samples that have low and high total gas contents in order to determine differences in the gas storage capacities of the various coals. Langmuir isotherms will be compared within and between coal beds as well as comparing geographic, stratigraphic, and depth differences. (Note: Isotherm values discussed below are all given on an as-received basis.)

\section{Powder River Basin}

\section{Langmuir Isotherms Within and Between the Same Coal Bed}

In order to determine the variations of gas-holding capacity within a coal bed, 6 samples from the Big George coal were analyzed for adsorption and Langmuir isotherms in the MichiWest Pilot 16-14 well (see core hole 1 isotherms,
Appendix III, depth intervals 1,221-1,223 ft, 1,231-1,233 ft, $1,284-1,286 \mathrm{ft}, 1,332-1,334 \mathrm{ft}, 1,351-1,353 \mathrm{ft}$, and 1,359-1,361

$\mathrm{ft}$, which span the entire bed). The total gas content of these 6 samples ranges from as low as $16.82 \mathrm{scf} / \mathrm{t}$ in the upper part of the coal bed (canister 10) to as much as $77.45 \mathrm{scf} / \mathrm{t}$ in the middle part (canister 48). The Langmuir isotherm of the coal in canister 10 indicates gas volume or holding capacity of 182 cubic feet/ton $\left(\mathrm{ft}^{3} / \mathrm{t}\right)$ on an as-received basis of coal at $798 \mathrm{psia}$ pressure (pounds per square inch absolute). The gas volume for the coal in canister 48 is $220 \mathrm{ft}^{3} / \mathrm{t}$ at $605 \mathrm{psia}$.

Based on the Langmuir isotherms of the 6 Big George coal samples (core hole 1, Appendix III), the gas volume storage capacity differs vertically from lower to upper parts of the bed. The lower part (depth 1,332-1,361 ft) can ideally store from $207-279 \mathrm{ft}^{3} / \mathrm{t}$ at 571-918 psia and the upper part (depth 1,221-1,286 ft), can ideally store from $171-230 \mathrm{ft}^{3} / \mathrm{t}$ at 529-911 psia.

The Langmuir isotherms of the Big George coal bed in the nearby MichiWest 16-32 well (core hole 2, Appendix III) are about the same as those in MichiWest 16-14 well. In the 16-32 well, the coal bed, at the depth of 1,119-1,119.6 ft, can ideally store gas volumes of $184-234 \mathrm{ft}^{3} / \mathrm{t}$ at $478-681 \mathrm{psia}$. The coal bed with lower holding capacity is at 1,119-ft depth and the higher holding capacity is at 1,177-ft depth. The total desorbed gas content for the coal bed with the lowest Langmuir holding capacity is between 73 and $79 \mathrm{scf} / \mathrm{t}$, whereas that for the bed with the highest Langmuir holding capacity is between 63 and $72 \mathrm{scf} / \mathrm{t}$.

\section{Langmuir Isotherms Between Stratigraphically Different Coal Beds}

Langmuir isotherm variations between two stratigraphically different coal beds in the same core hole were studied in the Barrett Resources Corporation Hass 32-31 well (see core hole 5,Appendices II and III). In this core hole, the Big George coal bed is about $290 \mathrm{ft}$ above the Wyodak coal bed. In the depth interval 1,079-1,080 ft, the Langmuir isotherm indicates a gas volume holding capacity of $60 \mathrm{ft}^{3} / \mathrm{t}$ at $356 \mathrm{psia}$ and a coal sample at about the same depth (Appendix II, core hole 5, canister 15) has a total desorbed gas content about $16 \mathrm{scf} / \mathrm{t}$. The Langmuir isotherm of the Wyodak coal bed (depth 1,401-1,402 $\mathrm{ft}$ ) indicates gas storage capacity of $92 \mathrm{ft}^{3} / \mathrm{t}$ at 613 psia and a total gas content between 28.91 and $29.31 \mathrm{scf} / \mathrm{t}$ in a sample at about the same depth. Thus, the deeper Wyodak coal bed ideally stores more gas than the shallower Big George coal bed.

Langmuir isotherms for coal beds that are stratigraphically lower in the Tongue River Member of the Fort Union Formation than the Big George and Wyodak coal beds are

Figure 12 (following page). Relations of total gas content with percent maceral types or lithotypes, density, and Gamma Ray logs in the MichiWest Energy 16-32 well. scf/t, standard cubic feet of gas per short ton of coal; g/cc, grams per cubic centimeter. 


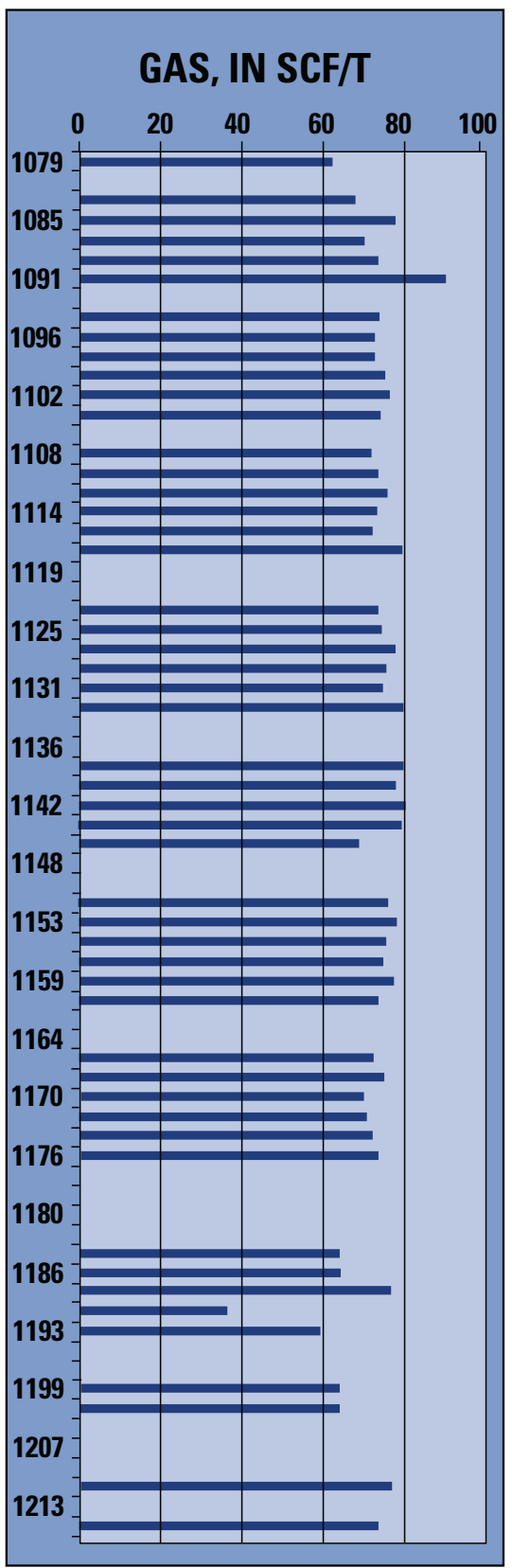

Explanation for Lithology:

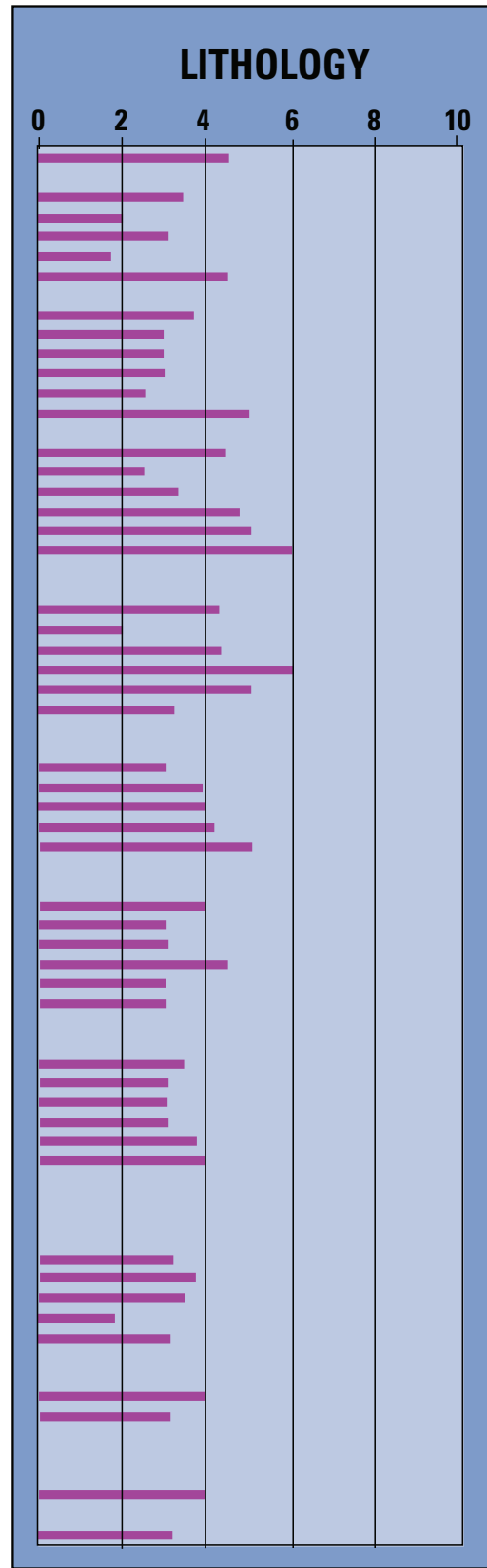

$1=$ Attritus

2 = Finely laminated attritus

3 = Medium-coarse laminated attritus
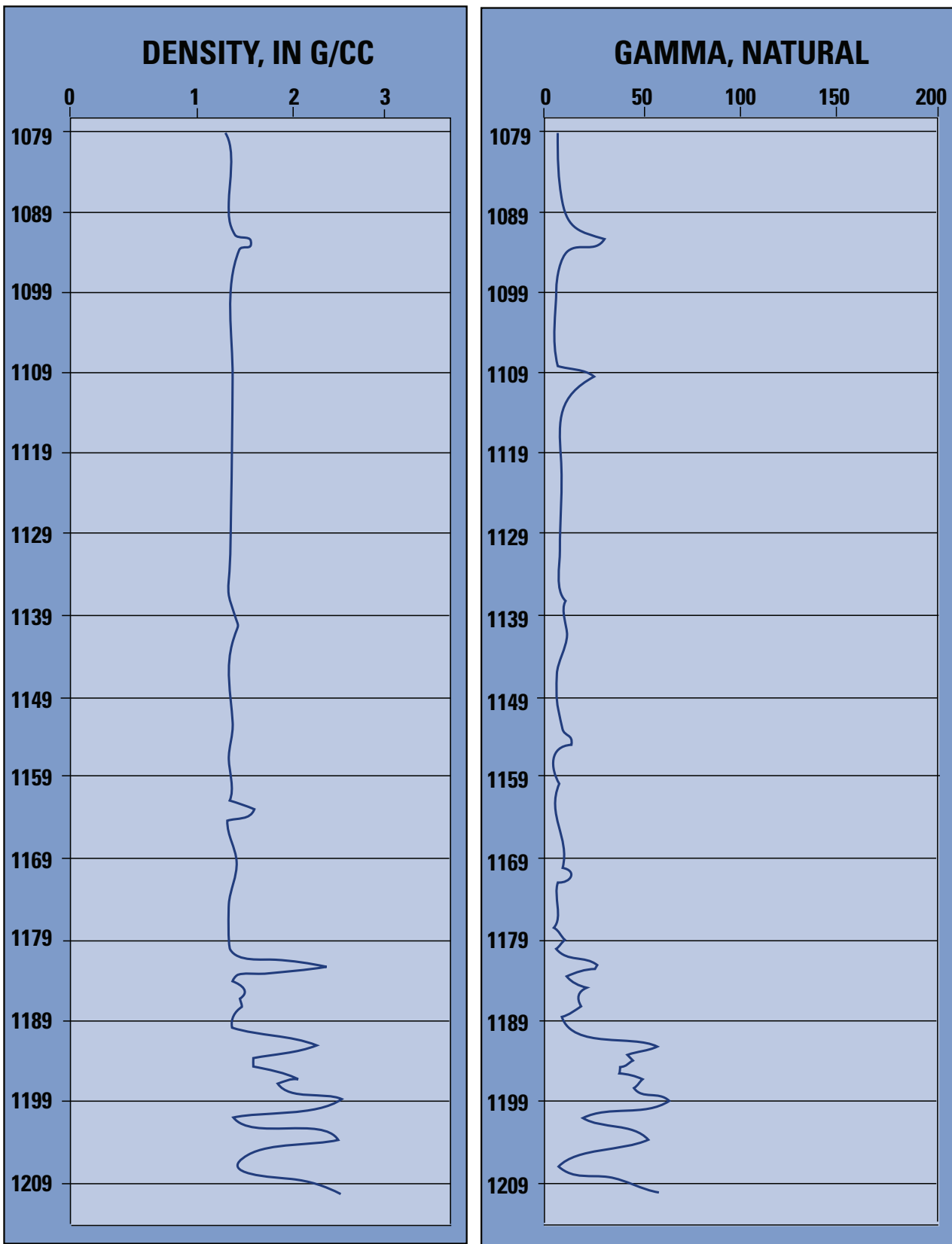

$4=$ Very coarsely laminated attritus

$5=$ Woody texture

$6=$ Woody hard texture 


\section{GAS CONTENT vS. LITHOTYPES}

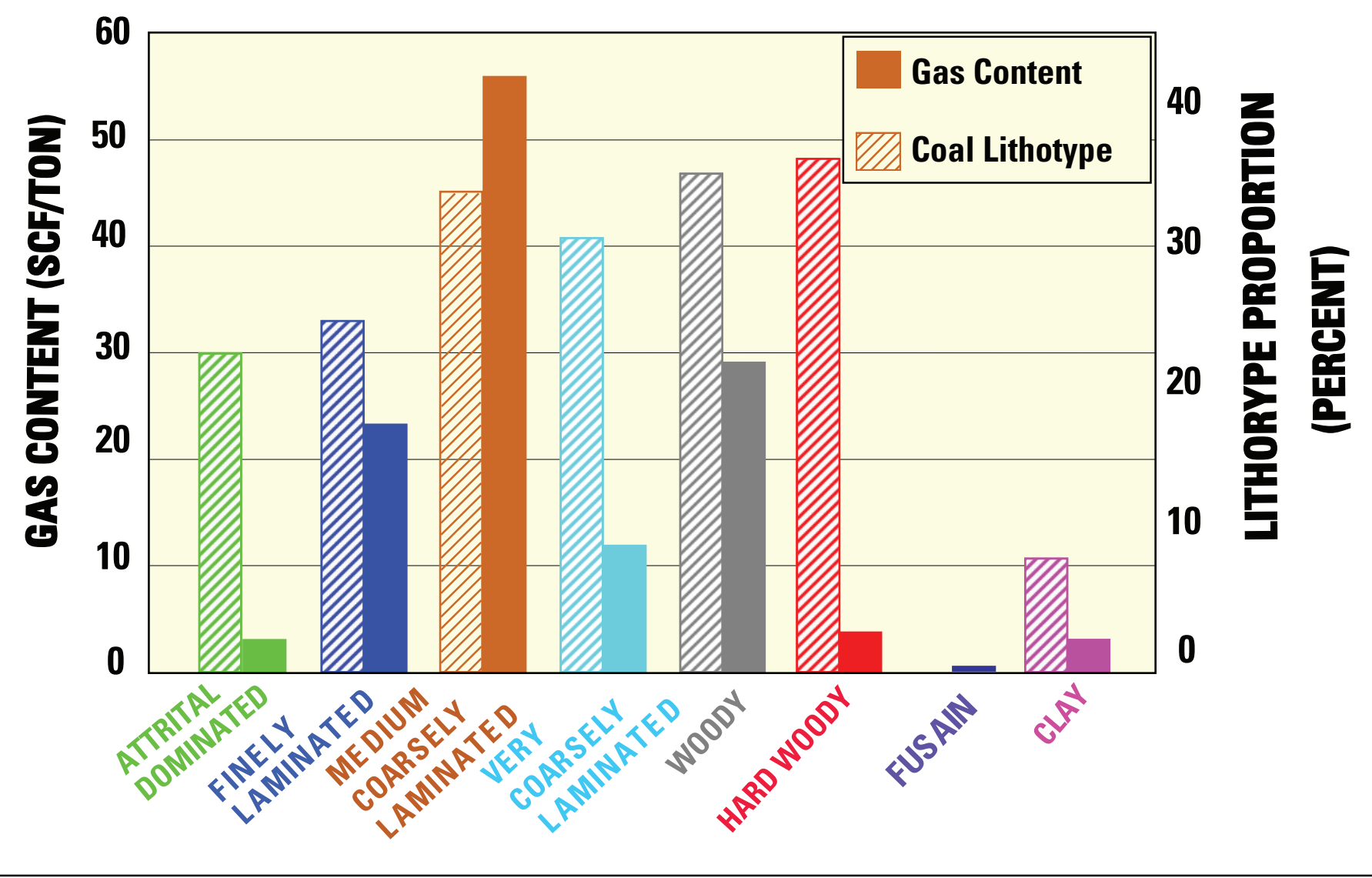

Figure 13. General relations of total gas content and lithotypes in the MichiWest Energy 16-32 well. Gas content is high in the woody and medium- to coarse-laminated attrital macerals. scf/t, standard cubic feet of gas per short ton of coal.

exemplified by the coal beds in the Pennaco Energy Sorenson 2-33-54-74W well (see core hole 4, Appendix III). The Langmuir isotherm of the Cook coal bed at 829-ft depth indicates gas volume storage capacity of $165 \mathrm{ft}^{3} / \mathrm{t}$ at $1,142 \mathrm{psia}$, and the total gas content of the sample was $19.73 \mathrm{scf} / \mathrm{t}$ (Appendix II, core hole 4, canister A11). The Langmuir isotherms of the Wall coal bed at depths of 1,155 and 1,168 ft indicate gas volume storage capacity of $182 \mathrm{ft}^{3} / \mathrm{t}$ at $1,056 \mathrm{psia}$ and $156 \mathrm{ft}^{3} / \mathrm{t}$ at 1,056 psia, respectively. Total gas content of the coal sample near the 1,155-ft depth ranges from 34.22-37.91 scf/t, and for the sample near the 1,168-ft depth, the range is $36.16-37.40$ scf/t. Thus, the deeper Wall coal bed stores about the same gas volume as the shallower Cook coal bed.

\section{Langmuir Isotherms of Coal Beds at Various Depths}

The Langmuir isotherm of the deepest well, which penetrated the Roberts coal bed in the depth interval 2,190-2,204-ft in the Nance Petroleum Remington 57-79-18-03R well, indicates gas volume storage capacity of $331 \mathrm{ft}^{3} / \mathrm{t}$ at $1,174 \mathrm{psia}$ (core hole 29, Appendices II and III). The coal sample contains total gas as low as $72.41 \mathrm{scf} / \mathrm{t}$ and ash yield as much as 38.58 percent. Other coal beds such as the Pawnee coal in the Peabody Natural Gas 24-1 and 26-1 wells contain much lower gas storage capacity - Langmuir isotherms for this coal vary from $174-177 \mathrm{ft}^{3} / \mathrm{t}$ at $648-843$ psia and gas content range from 2.58$6.16 \mathrm{scf} / \mathrm{t}$ (see core holes 36 and 37, Appendices II and III).

The shallowest coal samples in this study, ranging in depth from 206 to $407 \mathrm{ft}$, are in the Peabody Natural Gas wells (PNG 34-1, PNG 33-1, PNG 31-1, and PNG 35-1), Kennecott Energy CBM 1 and CBM 2, and Rim Operating CBM H 11-04 and CBM C 33-1R. The Langmuir isotherms for the Wyodak coal bed in the Peabody Natural Gas coreholes (see core holes 15,16 , and 18, see Appendix III) vary from 100-141 $\mathrm{ft}^{3} / \mathrm{t}$ at 433 to 583 psia, and the total desorbed gas contents vary from 0.92-15.87 scf/t (Appendix II). The isotherms of the Wyodak coal bed in the Rim Operating coreholes (core holes 13, 14, 
Appendix III) vary from Langmuir volumes of $16-175 \mathrm{ft}^{3} / \mathrm{t}$ at Langmuir pressures of 187-617 psia, and the total desorbed gas contents vary from 1.96-13.03 scf/t (Appendix II). The Kennecott Energy core holes are about 1-2 miles south and southeast of the Rim Operating coreholes and penetrate the mineable Wyodak coal bed. The Langmuir isotherm of the coal bed varies from volumes of $45-73 \mathrm{ft}^{3} / \mathrm{t}$ at pressures of 161-351 psia (core holes 9, 10, Appendix III) and the total desorbed gas contents range from 2.21-2.72 scf/t for the Kennecott Energy CBM 1 core hole and 0.83-1.64 scf/t in the Kennecott Energy CBM 2 core hole (Appendix II).

\section{Other Basins}

\section{Williston Basin}

The Langmuir isotherms of the lignite coal beds in the WB vary from Langmuir volumes of 31 to $173 \mathrm{ft}^{3} / \mathrm{t}$ at Langmuir pressures of 685-1,605 psia (see core holes 7, 21, 22, Appendix III). The shallow mineable Beulah coal bed has the highest gas storage capacity of $173 \mathrm{ft}^{3} / \mathrm{t}$ at $1,605 \mathrm{psia}$, and a sample of the core has total desorbed gas content of $0.88 \mathrm{scf} / \mathrm{t}$ (core hole 21 , Appendix II). The deepest coal bed (unnamed) has gas storage capacity of $31 \mathrm{ft}^{3} / \mathrm{t}$ at $727 \mathrm{psia}$ (core hole 7 , Appendix III and a total desorbed gas content of $1.02 \mathrm{scf} / \mathrm{t}$ (Appendix II).

\section{Green River Basin}

The Langmuir isotherm of the subbituminous Deadman coal bed in the Green River Basin is $173 \mathrm{ft}^{3} / \mathrm{t}$ at $407 \mathrm{psia}$ (core hole 24, Appendix III). A coal sample has a total gas content of $0.98 \mathrm{scf} / \mathrm{t}$ (Appendix II).

\section{Interpretations of Langmuir Isotherm Results}

The average adsorption isotherm of the subbituminous coals in the Powder River Basin is shown in figure 14 constructed from analysis of 70 coal samples. The average adsorption isotherm shows increasing total gas content (scf/t) with increased pressure (psia). However, the total adsorbed gas content is more variable at higher pressure as indicated by the increasing interval between the +1 and -1 standard deviations in which 68 percent of the isotherm data lies. Thus, the average methane adsorption isotherm curve may, in general, indicate the ideal storage capacity for subbituminous coals in the Powder River Basin. And, by inference, the possible storage capacity for subbituminous coal in unexplored basins

The average isotherm of the lignite coals in the Williston Basin is shown in figure 15, based on data from 3 coal samples. The average isotherm behaves similarly to that of the Powder River Basin; however, the average Langmuir volumes are lower.
The Langmuir isotherm, which is the ideal gas storage capacity of the coal beds, varies within and between coal beds, with coal bed, and between geographic areas. The Big George coal bed in the MichiWest Energy coreholes, for example, shows greater gas storage capacity in the lower part than in the upper part. Gas storage capacity may also be partly controlled by ash yield and organic maceral composition. Chiehwosky and others (2003) suggested that the lower part of the Big George coal bed contains more coarse bands of woody macerals than the upper part, which contains more finely banded to non-banded attrital macerals (fine plant fragments). In addition, a study of the macerals of the Wyodak coal bed in the Peabody Natural Gas CBM 31-1, 35-1 by Moore and others (2001) showed that vitrain banding increases with depth. This suggests more gas storage capacity in the more woody lower part of the coal. This woody characteristic and vertical variation of the macerals of this thick coal bed was originally interpreted by Flores $(1981,1986)$ as a result of having accumulation in a domed mire peat in an ombrotrophic rain-fed bog in tropical climate. The absence of a large difference in gas storage capacity of the Big George coal bed within just the few hundred feet separating the MichiWest Energy core holes indicates a laterally homogeneous maceral composition.

Langmuir isotherm variations between coal beds may also be controlled, in part, by differences in maceral composition and ash yield. Possibly high ash yield, which is directly related to low gas volume storage capacity, had the greatest effect in the thinner coal beds, such as the Wall and Pawnee. Flores $(1981,2004)$ suggested that the thinner coal beds in the Powder River Basin formed in low-lying swamps, which were prone to flooding and deposition of fine-grained sediments. In general, the tendency of coal beds to have more gas volume storage capacity at the deeper horizons may be because of the greater hydrostatic pressure, which holds the gas molecules in place and minimizes degassing.

Geographic variations of the Langmuir isotherms of coal beds between the deeper and shallower parts of a basin appear to be significant. This is particularly highlighted by shallow coal beds around the coal mines near Gillette, Wyoming, where pressures related to the holding capacity of the coal beds are lower than those in deeper wells. This may, in part, be related to differences in hydrostatic pressures that were depleted due to lowering of groundwater level at the shallower depths by dewatering of the coal mines for the past few decades.

\section{Apparent Rank Difference of Coal Beds}

The Langmuir isotherms of the lignite in the Williston Basin and subbituminous coal in the Green River Basin indicate a significant difference in gas volume storage capacity. The isotherms for Williston Basin lignite have a Langmuir volume as low as $31 \mathrm{ft}^{3} / \mathrm{t}$ (on an as-received basis), while the subbituminous coal of the Green River Basin has a Langmuir volume of $173 \mathrm{ft}^{3} / \mathrm{t}$ (on an as-received basis). Thus, gas storage capacity is directly related to coal-bed rank, which in turn may be related to depth of burial and maturation of the coal. 


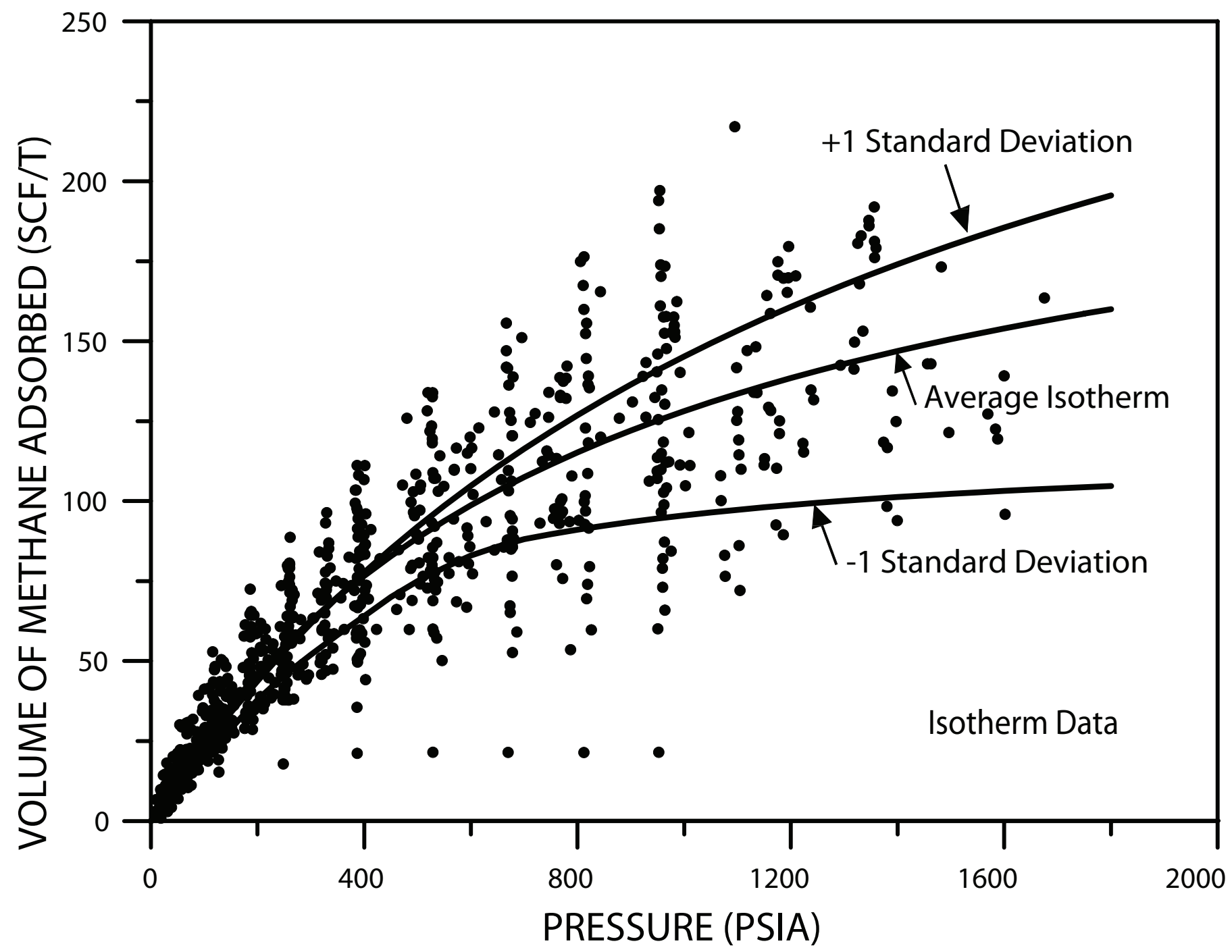

Figure 14. Average methane adsorption isotherm curve of subbituminous coals in the Powder River Basin, Wyoming and Montana. scf/t, standard cubic feet of gas per short ton of coal; psia, pounds per square inch absolute.

\section{Summary}

Adsorption isotherms of coal beds in the Paleocene Fort Union Formation in the Powder River, Williston, and Green River Basins, based on desorption and gas storage capacity measurements, show that total gas contents vary stratigraphically and geographically, as well as within an individual coal bed.

Stratigraphically, total gas content and gas storage capacity vary vertically in that the deeper coal beds typically are more gassy and can store more gas than shallower beds, which is probably a function of depth as well as greater hydrostatic pressures. The coal beds in the shallowest part of the Powder River Basin are strip mined, an operation that includes dewatering the coal near mines. Dewatering lowers the groundwater level, decreases the hydrostatic pressure, and gradually drains the gas from the immediate outlying areas of the coal mines. Continued dewatering in the coal mines causes depletion of hydrostatic pressure basinward by as much as 20 psia (McGarry, pers. comm., 2005).

Within a coal bed, the total gas content and gas storage capacity also vary significantly depending on the ash yield and maceral composition. For example, coal beds containing high ash or inorganic matter contain less gas; inorganic matter or ash are poor gas absorbents, whereas organic matter is more effective in adsorbing gas. However, adsorption is also dependent on the woody content of the coal; the ombrotrophic raised-bog origin of the coal beds influences the vertical distribution of the gas - that is, the woody lower part of the thick coal beds contained and adsorbed more methane than the less woody, attritus-rich upper part.

The results of our study show that the total gas content of the Fort Union coal beds in the Powder River Basin is much lower than the ideal gas volume storage capacity of the coal beds, which indicates that the coal beds are undersaturated 


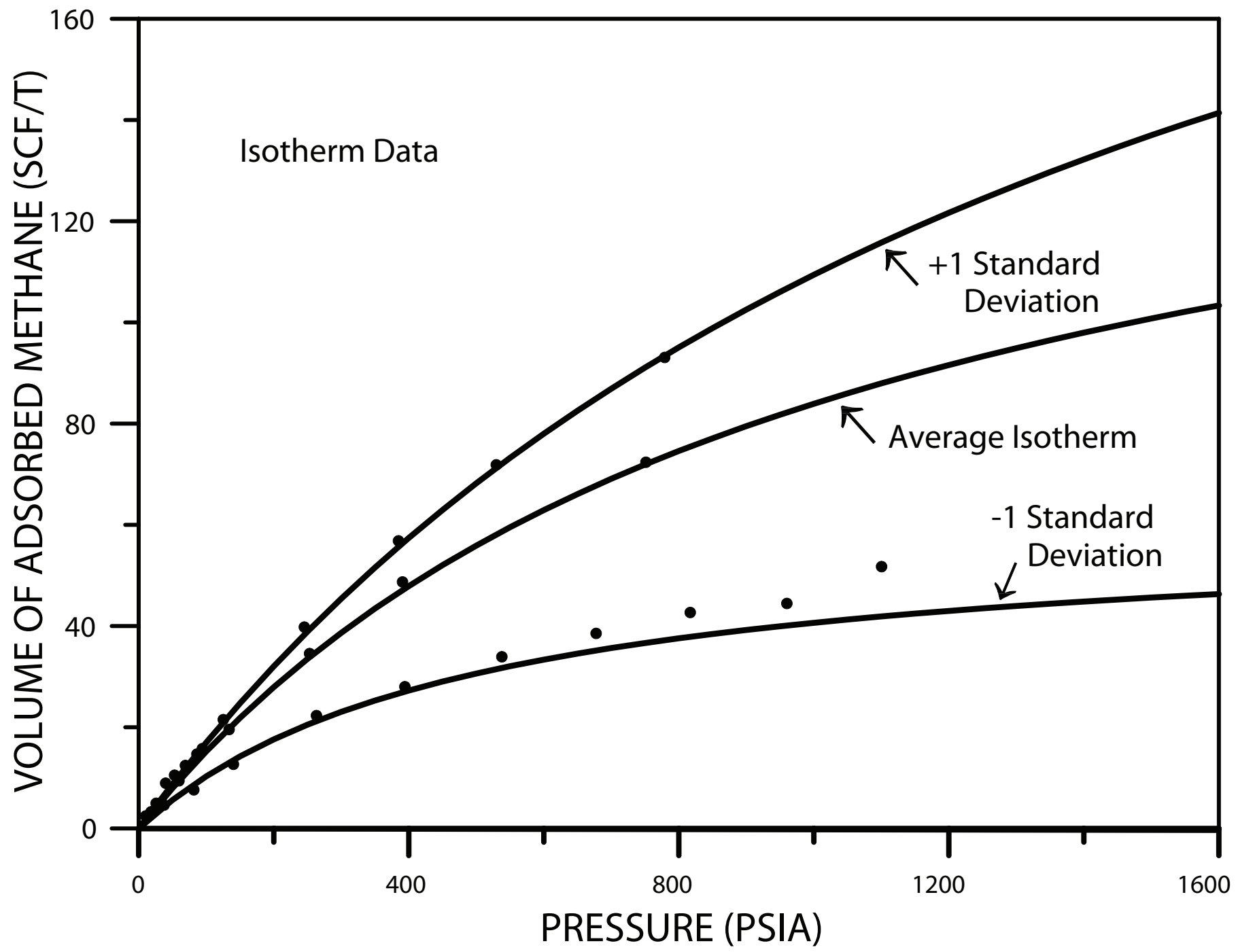

Figure 15. Average methane adsorption isotherm curve of lignite coals in the Williston Basin, Montana and North and South Dakota. scf/t, standard cubic feet of gas per short ton of coal; psia, pounds per square inch absolute.

with gas. In that regard, previous studies by Stricker and Flores (2003) have shown that gas undersaturation ranges from 23 to 66 percent, and is a function of coal bed rank and coal depth.

\section{Acknowledgments}

The authors acknowledge the excellent and helpful comments of W. Roger Miller ( BLM Casper, Wyoming) and Timothy J. Rohrbacher, Douglas J. Nichols, and W.R Keefer (U.S. Geological Survey, Denver, Colorado) in their reviews of this paper. Thanks are also due to Carol M. Olson and Jonah E. Sullivan for drafting the color figures. The valuable support of the many gas operators, who have supplied core, and the BLM and USGS personnel, who helped collect coal core and desorb the coal gas, is also gratefully acknowledged.

\section{References Cited}

Boreck, D.L., and Weaver, J.N., 1984, Coalbed methane study of the Anderson coal deposit, Johnson County, Wyominga preliminary report: U.S. Geological Survey Open-File Report 84-831, 16 p. A-354.

Chiehowsky, L.A., Flores, R.M., Stricker, G.D., Stanton, R.W., Trippi, M.H., Nichols, D.J., and Warwick, P.D., 2003, Coal Composition and gas content of the Big George Coal Bed, Johnson County, Wyoming [abs]: Geological Society of America, Rocky Mountain Section, 55th Annual Meeting, Durango, CO, May 7-9, 2003: Geological Society of America Abstracts with Programs, v. 35, no. 5, p. 38. 
Crockett, F.J., 2002, Coalbed methane development in the Powder River Basin, Wyoming [abs]: Geological Society of America Annual Meeting Abstracts with Programs, Boston, MA November 7, 2001, v. 33, no. 6, page A354.

Crockett, F.J., Ellis, M.S., Stricker, G.D., Gunther, G.L., Ochs, A.M., and Flores, R.M., 2001, An estimate of recoverable coal gas resources in the Powder River Basin, Wyoming, in Stilwell, D.P., ed., Wyoming Gas Resources and Technology: 52nd Field Conference Guidebook, Wyoming Geological Society, p. 183-189.

Diamond, W.P., and Schatzel, S.J., 1998, Measuring the gas content of coal: A review, in Flores, R.M. ed., Coalbed Methane: From Coal-Mine Outbursts to A Gas Resource: International Journal of Coal Geology, v. 35, p.311-331.

Diamond, W.P., and Levine, J.R., 1981, Direct method determination of the gas content of coal: Procedures and results: U. S. Department of the Interior, Bureau of Mines Report of Investigations $8515,36 \mathrm{p}$.

Finley, A.K., and Goolsby, J.E., 2000, Estimates of coal volumes and coalbed methane in place, Powder River Basin, Wyoming: Wyoming Geo-notes, Number 68, p. 16-18.

Flores, R.M., 1981, Coal deposition in fluvial paleoenvironments of the Paleocene Tongue River Member of the Fort Union Formation, Powder River area, Powder River Basin, Wyoming and Montana, in Ethridge, F.G. and Flores, R.M., eds., Nonmarine Depositional Environments: Models for Exploration: Society of Economic Paleontologists and Mineralogists, Special Publication 31, p. 169-190.

Flores, R.M., 1986, Styles of coal deposition in Tertiary alluvial deposits, Powder River Basin, Montana and Wyoming, in Lyons, P.C. and Rice, C.L., eds., Paleoenvironmental and Tectonic Controls in Coal-forming Basins of the United States: Geological Society of America, Special Paper 210, p. 79-104.

Flores, R.M., 2004, Upper Cretaceous-Tertiary Total Petroleum System on coalbed methane in the Powder River Basin, Montana and Wyoming; U.S. Geological Survey Digital Data Series-69-C, Chapter 2, CD-Rom version 1.

Flores, R.M., McGarry, D.E., and Stricker, G.D., 2005, CBNG development: Confusing coal stratigraphy and gas production in the Powder River Basin, in Coalbed Methane: Back to Basics of Coal Geology: Canadian Society of Petroleum Geologists, 2005 Gussow Geoscience Conference, Abstracts, p. 13.

Fort Union Coal Assessment Team, 1999, 1999 Resource assessment of selected Tertiary coal beds and zones in the northern Rocky Mountains and Great Plains region: U.S. Geological Survey Professional Paper 1625-A, Discs 1 and 2, Version 1.1.
Hobbs, R.G., 1978, Methane occurrences, hazards, and potential resources: Recluse Geologic Analysis Area, northern Campbell County, Wyoming: U.S. Geological Survey OpenFile Report 78-401, 20 p.

Lowry, M.E., and Cummings, T.R., 1966, Groundwater resources of Sheridan County, Wyoming: U.S. Geological Survey Water-Supply Paper 1807, 77 p.

Mavor, M.J., and Nelson, C.R., 1997, Coalbed reservoir gasin-place analysis: Gas Research Institute, GRI Report No. GRI-97/0263, p. 3.1-3.20.

Mavor, M.J., Owen, L.B., and Pratt, T.J., 1990, Measurement and evaluation of isotherm data: Proceedings of the $65^{\text {th }}$ Annual Technical Conference and Exhibition of the Society of Petroleum Engineers, SPE 20728, p. 157-170.

McCulloch, C.M., Levine, J.R., Kissel, F.N., and Deul, Maurice, 1975, Measuring the methane content of bituminous coalbeds: U.S. Bureau of Mines Report of Investigation 8043,22 p.

Moore, T.A., Flores, R.M., Stanton, R.W., and Stricker, G.D., 2001, The role of macroscopic texture in determining coalbed methane variability in the Anderson-Wyodak coal seam, Powder River Basin, Wyoming: The Society for Organic Petrology, Eighteenth Annual Meeting, Houston, Texas, v. 18, p. 85-88.

Nichols, D.J., 1994, Palynostratigraphic correlation of Paleocene rocks in the Wind River, Bighorn, and Powder River basins, Wyoming, in Flores, R.M., Mehring, K.T., Jones, R.W., and Beck, T.L., eds., Organics and the Rockies Field Guide: Wyoming State Geological Survey Public Information Circular No. 33, p. 17-29.

Olive, W.W., 1957, The Spotted Horse coal field, Sheridan and Campbell Counties, Wyoming: U.S. Geological Survey Bulletin 1050, 83 p.

Rice, D.D., and Finn, T.M., 1996, Powder River Basin (033), in Gautier, D.L., Dolton, G.L., Takahashi, K.I., and Varnes, K.L., eds., 1995 National Assessment of United States Oil and gas Resources - Results, Methodology, and Supporting data: U.S. Geological Survey Digital Data Series DDS-30, p. 40-46.

Stricker, G.D., and Flores, R.M., 2003, Lost gas and drainage due to coal mining and development in the Powder River Basin: Coalbed Methane Workshop and 3rd ASEAN Forum on Coal (AFOC) Council Meeting, Directorate General of Geology and Mineral Resources of Indonesia, Asean Centre for Energy and Asean Forum on Coal, Jakarta, Indonesia, Book 2, 87 p. 
Stricker., G.D. and Flores, R.M., 2002, Coalbed methane content in the Powder River Basin, Wyoming: Saturation by coal rank and depth: Nineteenth Annual International Pittsburgh Programs, Pittsburgh, PA, September 22-27, 2002: [CD ROM] without pagination, Session 6, 15 p. ISBN 1-890977-19-5.

Whitcomb, H.A., Cummings, T.R., and McCullough, R.A., 1966, Groundwater resources and geology of northern and central Johnson County, Wyoming: U.S. Geological Survey Water-Supply Paper 1806, 99 p. 